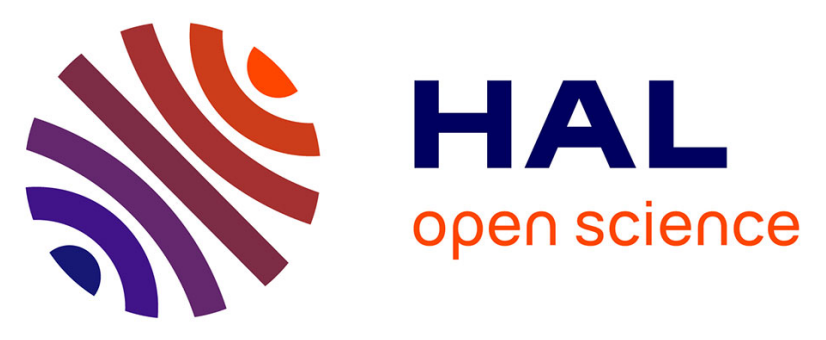

\title{
Evidencing 98 secondary metabolites of Penicillium verrucosum using substrate isotopic labeling and high-resolution mass spectrometry
}

Thaïs Hautbergue, Olivier Puel, Souria Tadrist, Lauriane Meneghetti, Michel

Péan, Marcel Delaforge, Laurent Debrauwer, Isabelle P. Oswald, Emilien L. Jamin

\section{To cite this version:}

Thaïs Hautbergue, Olivier Puel, Souria Tadrist, Lauriane Meneghetti, Michel Péan, et al.. Evidencing 98 secondary metabolites of Penicillium verrucosum using substrate isotopic labeling and high-resolution mass spectrometry. Journal of Chromatography B - Analytical Technologies in the Biomedical and Life Sciences, 2017, in press, 10.1016/j.jchromb.2017.03.011 . hal-01607721

\section{HAL Id: hal-01607721 \\ https://hal.science/hal-01607721}

Submitted on 26 May 2020

HAL is a multi-disciplinary open access archive for the deposit and dissemination of scientific research documents, whether they are published or not. The documents may come from teaching and research institutions in France or abroad, or from public or private research centers.
L'archive ouverte pluridisciplinaire HAL, est destinée au dépôt et à la diffusion de documents scientifiques de niveau recherche, publiés ou non, émanant des établissements d'enseignement et de recherche français ou étrangers, des laboratoires publics ou privés. 


\section{Accepted Manuscript}

Title: Evidencing 98 secondary metabolites of Penicillium verrucosum using substrate isotopic labeling and high-resolution mass spectrometry

Authors: Thaïs Hautbergue, Olivier Puel, Souria Tadrist, Lauriane Meneghetti, Michel Péan, Marcel Delaforge, Laurent

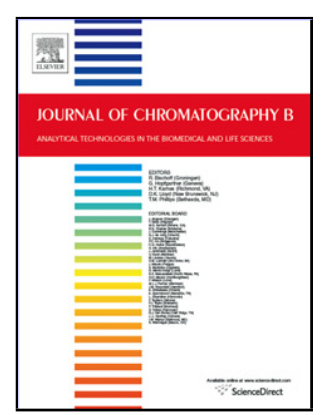
Debrauwer, Isabelle P. Oswald, Emilien L. Jamin

PII:

DOI:

S1570-0232(17)30403-8

Reference: http://dx.doi.org/doi:10.1016/j.jchromb.2017.03.011

To appear in: $\quad$ Journal of Chromatography B

Received date: $\quad 27-10-2016$

Revised date: 6-3-2017

Accepted date: $\quad 10-3-2017$

Please cite this article as: Thaïs Hautbergue, Olivier Puel, Souria Tadrist, Lauriane Meneghetti, Michel Péan, Marcel Delaforge, Laurent Debrauwer, Isabelle P.Oswald, Emilien L.Jamin, Evidencing 98 secondary metabolites of Penicillium verrucosum using substrate isotopic labeling and high-resolution mass spectrometry, Journal of Chromatography B http://dx.doi.org/10.1016/j.jchromb.2017.03.011

This is a PDF file of an unedited manuscript that has been accepted for publication. As a service to our customers we are providing this early version of the manuscript. The manuscript will undergo copyediting, typesetting, and review of the resulting proof before it is published in its final form. Please note that during the production process errors may be discovered which could affect the content, and all legal disclaimers that apply to the journal pertain. 


\title{
Evidencing 98 secondary metabolites of Penicillium verrucosum using
}

\section{substrate isotopic labeling and high-resolution mass spectrometry}

Thaïs Hautbergue ${ }^{\mathrm{a}, \mathrm{b}}$, Olivier Puel ${ }^{\mathrm{a}, *}$, SouriaTadrist $^{\mathrm{a}}$, Lauriane Meneghetti ${ }^{\mathrm{a}, \mathrm{b}}$, Michel Péan ${ }^{\mathrm{c}, \mathrm{d}, \mathrm{e}}$, Marcel Delaforge ${ }^{\mathrm{f}}$, Laurent Debrauwer ${ }^{\mathrm{a}, \mathrm{b}}$, Isabelle P. Oswalda, Emilien L. Jamin ${ }^{\mathrm{a}, \mathrm{b}}$

a Toxalim, Université de Toulouse, INRA, INP-ENVT, INP-EI-Purpan, Univ. Toulouse 3 Paul Sabatier, 31027 Toulouse, France

${ }^{\text {b }}$ Axiom Platform, MetaToul-MetaboHUB, National Infrastructure for Metabolomics and Fluxomics, 31027 Toulouse, France ${ }^{\mathrm{c}}$ Groupe de Recherches Appliquées en Phytotechnologie, CEA, IBEB, Cadarache, FR 13108 Saint-Paul-les-Durance, France

${ }^{\mathrm{d}}$ UMR Biologie Végétale et Microbiologie Environnementale, CNRS, FR 13108 Saint-Paul-les-Durance, France

${ }^{e}$ Université d'Aix-Marseille, FR 13007 Marseille, France

${ }_{\mathrm{f}}^{\mathrm{f}}$ CNRS, URA 2096, CEA Saclay, FR 91191 Gif sur Yvette, France

* Corresponding author: olivier.puel@ toulouse.inra.fr

\section{Highlights}

- Double stable isotope labeling of substrate for labeling the fungal metabolites

- Evidencing of 98 secondary metabolites produced by Penicillium verrucosum on wheat

- 82 unknown secondary metabolites detected on Penicillium verrucosum by HPLC-HRMS

- Detailed MS and MS/MS data of all detected unknown metabolites

\begin{abstract}
Industrial applications of fungal compounds, coupled with the emergence of fungal threats to natural ecosystems and public health, have increased interest in filamentous fungi. Among all pathogenic fungi, Penicillium verrucosum is one of the most common mold-infecting stored cereals in temperate regions. However, it is estimated that $80 \%$ of fungal secondary metabolites remain unknown. To detect new $P$. verrucosum compounds, an untargeted metabolomic approach was applied to fungus
\end{abstract}


grown on wheat grains labeled with stable isotopes: (i) natural grains $\left(99 \%{ }^{12} \mathrm{C}\right)$; (ii) grains enriched with $97 \%$ of ${ }^{13} \mathrm{C}$; and (iii) grains enriched with $53 \%$ of ${ }^{13} \mathrm{C}$ and $97 \%$ of ${ }^{15} \mathrm{~N}$. Analyses performed by highperformance liquid chromatography coupled with high-resolution mass spectrometry (HPLC-HRMS) enabled the specific detection of fungal metabolites, and the unambiguous characterization of their chemical formulas. In this way, 98 secondary metabolites were detected and their chemical formulas were determined. Of these, only 18 identifications could be made based on databases, the literature and mass spectrometry fragmentation experiments, with the result that 80 were totally unknown. Molecular networks were generated to analyze these results, leading to the characterization by $\mathrm{MS}^{\mathrm{n}}$ experiments of a new fungisporin produced by $P$. verrucosum. More generally, this article provides precise mass spectrometric data about all these compounds for further studies of the Penicillium metabolome.

Key words: fungus; Penicillium verrucosum; mass spectrometry; stable isotope labeling; secondary metabolite; molecular networking

\section{Introduction}

Filamentous fungi are well-known for their ability to produce a wide range of secondary metabolites. These molecules are mostly involved in fungal defense and environmental adaptation systems [1]. Since the discovery of penicillin as the first antibiotic of fungal origin used for human health [2], natural compounds have attracted great interest in a variety of industrial areas. Today, $42 \%$ of the metabolites adapted for human health applications are derived from fungal compounds [3]. In the agrifood field, they are commonly used as plant-growth hormones [4] or food additives [5]. On the other hand, fungal secondary metabolites known as 'mycotoxins' produce deleterious effects directly on their vegetal hosts, but also indirectly through human food or livestock feed contamination. Mycotoxins are considered the most important chronic dietary risk factor, higher than pesticide residues [6]. Various types of toxicity are associated with fungal metabolites. Some of them display carcinogenic potential, such as aflatoxin, [7] or nephrotoxicity, such as ochratoxin A [8]. Others are estrogenic mycotoxins such as zearalenone, 
which is involved in reproductive disorders of farm animals and in hyperestrogenic syndromes in humans [9]. Moreover, contaminations by mycotoxins produce major economic consequences, due to the destruction of crops and stocks [10]. Today, although several hundreds of secondary metabolites are characterized as mycotoxins and about 30 are considered of human and animal health concern, only six of them are regulated. Furthermore, fungal genome observations suggest that $80 \%$ of their secondary metabolome remains unknown, highlighting the great proportion of compounds still to be discovered [11].

Penicillium verrucosum is one of the most common molds infecting stored cereals in temperate regions [12]. Its ability to grow at mild temperatures can lead to the infection of grains during their storage, particularly in case the drying or re-moistening process fails $[8,13]$. In Canada, annual economic losses due to the elimination and destruction of infected cereals stocks are estimated to be over 260 million Canadian dollars [14]. Moreover, ochratoxin A, the major mycotoxin of P. verrucosum, is considered to be the most potent renal carcinogen of natural origin [15], and is classified as a possible human carcinogen (Group 2B) [16]. According to some studies, ochratoxin A could be the cause of Balkan Endemic Nephropathy (BEN), a fatal disease first recorded in 1956 [17-19]. Some other secondary metabolites of $P$. verrucosum have been characterized, such as citrinin (nephrotoxic) and ochratoxin B (an unchlorinated intermediate of ochratoxin A biosynthetic pathway), which are considered as mycotoxins, and some metabolites belonging to the families of verrucolones and verrucines [20].

Among the relevant analytical techniques for the characterization of secondary metabolites, untargeted metabolomics using High-Resolution Mass Spectrometry (HRMS) are particularly interesting [21]. This technique enables the detection of both known and unknown metabolites, and the determination of their exact mass, and contributes to their structural identification. However, data interpretation remains complex due to the non-specific detection of compounds including both metabolites and contaminants, and the difficulty of achieving unambiguous chemical formulas, even with highly accurate mass measurement [22]. To overcome these difficulties, a number of original analytical approaches using stable isotope labeling (SIL) have been developed. Bueschl et al. pointed out the benefits provided by this 
strategy for the specific detection of the metabolites, as well as for the characterization of the global biochemical composition of biological samples [23]. One SIL strategy consists of growing a fungus on the non-labeled glucose medium $\left({ }^{12} \mathrm{C}\right)$ as well as on the fully ${ }^{13} \mathrm{C}$ labeled glucose. The two extracts are then pooled and analyzed by High-Performance Liquid Chromatography (HPLC) coupled with HRMS [24,25]. The detection of two mirror isotopic distributions enables the rapid determination of the number of carbon atoms in all the detected fungal metabolites, facilitating the determination of their chemical formula. However, for high-molecular weight compounds, a single isotope labeling might not be enough to obtain a unique chemical formula and another stable isotope labeling would be required.

Moreover, fungi modulate the synthesis of their secondary metabolites depending on their needs for the medium colonization. This principle, commonly called OSMAC (One Strain Many Compounds), means that every small change in growth conditions can completely alter the fungal secondary metabolism. This implies that the fungal metabolome should be studied in culture conditions as close as possible to its natural growth environment [26]. As stressed by Hallas-Moller et al. [27], the study of cereal-associated species such as $P$. verrucosum has indeed been chemically investigated, but only by outdated analytical systems and on laboratory culture media. Thus, a SIL method based on the growth of plant pathogens on labeled cereals was previously developed in our laboratory [28]. To avoid the formula ambiguity for high-molecular weight metabolites, two isotopic labelings were used by the HPLC-HRMS analysis of carbon $13\left({ }^{13} \mathrm{C}\right)$ and nitrogen $15\left({ }^{15} \mathrm{~N}\right)$ labeled wheats. Below, following the successful validation of the method on the well-documented metabolism of Aspergillus fumigatus [28], we present the application to the saprophytic fungus $P$. verrucosum, with the aim of detecting unknown metabolites produced during wheat grain contamination.

\section{Materials and Methods}

\subsection{Chemicals and Reagents.}


The formic acid, and solvents used for sample preparation (ethyl acetate and methanol) and for the analyses (acetonitrile) were purchased from Fisher Scientific (Thermo Fisher Scientific, Illkirch, France). The ethyl acetate and methanol were HPLC grade and the acetonitrile was MS (mass spectrometry) grade. Ultrapure water was generated from a Milli-Q system (Millipore, Saint Quentin en Yvelines, France). Standards of ochratoxin A, citrinin and cyclopiazonic acid were purchased from Sigma (Sigma-Aldrich, Saint-Quentin Fallavier, France), and ochratoxin B was purchased from Fermentek (Fermentek Ltd, Jerusalem, Israel).

\subsection{Identification of Penicillium verrucosum.}

The study was performed on the strain NRRL 5571. Morphological identification was performed as recommended in the monograph of the Penicillium genus [29]. Genomic identification was conducted after DNA extraction. After 5 days of culture on YES medium (2.5 g of yeast extract, $10 \mathrm{~g}$ of glucose and $500 \mathrm{ml}$ of distilled water), fungal DNA was extracted. After grinding, the mycelium was incubated in an extraction buffer (CTAB 1\%, Tris-HCl pH 8100 mM, EDTA pH8 20 mM and NaCl 1.4 M)., Chloroform, phenol, and isopropanol were successively added. The pellet was washed with ethanol $70 \%$ and suspended in water. Amplification was performed with ITS (ITS 4 and 5) and $\beta$-tub (a and b) primers according to Adjovi et al. [30] and the PCR result was subjected to gel electrophoresis. Each isolated fragment was then purified with a GenElute PCR Clean-Up Kit (Sigma-Aldrich) and the DNA concentrations were measured with Nanodrop (ND-1000 program, Thermo Fisher Scientific, Illkirch, France). Then, they were sequenced by the dye terminator technology on an AB3130XL sequencer (Applied Biosystems). The DNA sequences of ITS and $\beta$-tubulin genes were finally compared by sequence alignment and deposited in GenBank under KY347870 and KY347871 accession numbers respectively.

\subsection{Production of ${ }^{13} \mathrm{C}$ - and ${ }^{13} \mathrm{C} /{ }^{15} \mathrm{~N}$ Labeled Wheats}

Uniform isotopic enrichments were performed on the variety Caphorn of Triticum aestivum as previously described [31]. Briefly, two different enrichments were achieved in hermetically sealed 
chambers $(750 \mathrm{~L})$ during a complete growth cycle, i.e. 6 months, with ${ }^{13} \mathrm{C}$-labeled $\mathrm{CO}_{2}$ and ${ }^{15} \mathrm{~N}$-labeled nitrate and ammonium salts: one nearly $100 \%{ }^{13} \mathrm{C}$ enriched wheat (referred to as ${ }^{13} \mathrm{C}$ wheat) and one nearly $50 \%{ }^{13} \mathrm{C}$ and nearly $100 \%{ }^{15} \mathrm{~N}$ wheat (referred to as ${ }^{13} \mathrm{C} /{ }^{15} \mathrm{~N}$ wheat). The isotopic enrichments were measured with a Delta V Advantage isotope ratio mass spectrometer (Thermo Fisher Scientific, Illkirch, France): $96.8 \% \pm 0.15 \%$ for the ${ }^{13} \mathrm{C}$ wheat, $53.4 \% \pm 0.3 \%{ }^{13} \mathrm{C}$ and $96.8 \% \pm 0.07 \%{ }^{15} \mathrm{~N}$ for the ${ }^{13} \mathrm{C} /{ }^{15} \mathrm{~N}$ wheat.

\subsection{Fungal Strain and Growth Conditions}

The natural and labeled wheat grains were soaked in water and autoclaved twice. The water activity $\left(a_{w}\right)$ of the grains was then measured with an HC2-AW measurement device (Rotronik AG, Basserdorf, Switzerland), and sterile water was added where necessary to reach an $\mathrm{a}_{\mathrm{w}}$ of 0.98 before inoculation. Thirty grams of each type of sterilized labeled wheat grains were placed in thin layers into sterile $140 \mathrm{~mm}$ diameter Petri dishes (Sarstedt, Marnay, France) to create a total of 4 culture media: one dish with ${ }^{13} \mathrm{C}$ wheat, one dish with ${ }^{13} \mathrm{C} /{ }^{15} \mathrm{~N}$ wheat and two dishes with ${ }^{12} \mathrm{C}$ wheat. The first three plates were inoculated with $250 \mu \mathrm{L}$ of a spore solution (at $10^{5}$ spore $/ \mathrm{mL}$ ) prepared from the PDA culture of the fungus. The second ${ }^{12} \mathrm{C}$ wheat Petri plate was used as a control and incubated in the same conditions as the other samples but without fungus. The fungal cultures were then placed in the dark without shaking for 1 month at $25^{\circ} \mathrm{C}$.

\subsection{Metabolite Extraction}

After incubation, the content of each Petri dish (wheat grains and mycelium) was extracted with 200 $\mathrm{mL}$ of ethyl acetate. After $36 \mathrm{~h}$ of shaking on a shaking table IKA Labor technik HS501 (IKA, Staufen, Germany) at $180 \mathrm{rpm}$, the extract was filtered and evaporated to dryness. The resulting residue was dissolved in $400 \mu \mathrm{L}$ of methanol and filtered with $0.45 \mu \mathrm{m}$ Whatman filters (Whatman, GE Healthcare, Kent, U.K.) before HPLC-HRMS analysis.

\subsection{Analytical Parameters} of Penicillium verrucosum using substrate isotopic labeling and high-resolution mass 
The extracts were analyzed by High-Performance Liquid Chromatography (HPLC) using an Ultimate 3000 system (Thermo Fisher Scientific, Les Ulis, France). A gradient program of $0.1 \%$ formic acid in water (phase A) and 100\% acetonitrile (phase B) was used as follows (flow rate, $0.2 \mathrm{~mL} / \mathrm{min}$ ): 0 min $20 \%$ of B, 30 min $50 \%$ of B, from 35 to 45 min $90 \%$ of B, from 50 to $6020 \%$ of $\mathrm{B}$. A volume of $10 \mu \mathrm{L}$ was injected on a reversed-phase Luna C18 column $(150 \mathrm{~mm} \times 2.0 \mathrm{~mm}, 5 \mu \mathrm{m})($ Phenomenex, Torrance, CA, U.S.A.). HPLC was coupled to a LTQ Orbitrap XL hybrid high-resolution mass spectrometer (Thermo Fisher Scientific, Les Ulis, France) using electrospray ionization (ESI) in the positive and negative modes. The ionization parameters were as follows: spray voltage $+4.5 \mathrm{kV}$, capillary temperature $350{ }^{\circ} \mathrm{C}$, sheath gas $\left(\mathrm{N}_{2}\right)$ flow rate 40 au (arbitrary units), auxiliary gas $\left(\mathrm{N}_{2}\right)$ flow rate 6 au for the positive mode, and spray voltage $-3.7 \mathrm{kV}$, capillary temperature $350{ }^{\circ} \mathrm{C}$, sheath gas flow rate 30 au $\left(\mathrm{N}_{2}\right)$, auxiliary gas flow rate 10 $\mathrm{au}\left(\mathrm{N}_{2}\right)$ for the negative mode. The full HRMS spectra were acquired at a resolution of 60,000 from $\mathrm{m} / \mathrm{z}$ 50 to $\mathrm{m} / \mathrm{z}$ 800. The high-resolution mass analyzer was calibrated in each ionization mode based on the supplier's protocol and calibration mixtures (Thermo Fisher Scientific, Les Ulis, France). The targeted MS/MS spectra were performed according to the following parameters: [Parameters for MS/MS by collision-induced dissociation $(\mathrm{CID})$ : resolution $=7500, \mathrm{MS}^{\mathrm{n}}$ maximum ion time $=200 \mathrm{~ms}$, isolation width $=1.5 \mathrm{Da}$, Act. $\mathrm{Q}=0.250$ and activation time= $30 \mathrm{~ms}$. [Parameters for MS/MS by higher energy collision dissociation $(\mathrm{HCD})$ : resolution $=7500, \mathrm{MS}^{\mathrm{n}}$ maximum ion time $=200 \mathrm{~ms}$, isolation width $=1.5$ $\mathrm{Da}$ and activation time $=30 \mathrm{~ms}] . \mathrm{HCD}$ and CID energies were adjusted to obtain appropriate fragmentation and maximum structural information. Since the analyses were performed to identify metabolites from a strictly qualitative point of view, neither quality control samples, nor replicates were necessary.

Analysis by HPLC coupled with diode-array-detection (Ultimate 3000 system, Thermo Fisher Scientific, Les Ulis, France) were performed to identify anacine. The chromatographic system and parameters were the same as for HPLC-HRMS analyses. The presence of anacine was monitored at a wavelength of $220 \mathrm{~nm}$.

\subsection{Identification of metabolites}


Comparisons of proposed ${ }^{12} \mathrm{C},{ }^{13} \mathrm{C}$ and ${ }^{13} \mathrm{C}^{15} \mathrm{~N}$ formulas were performed thanks to the MassCompare program developed in-house (http://www.toulouse.inra.fr/axiomm) using a measurement accuracy of 5 ppm. C, H, O, N, S, P, Cl, K and Na were the only accepted elements.

Identifications of metabolites were classified according to the Metabolomics Standard Initiative [32]. Metabolites identified at level 1 in our results displayed the same retention time, chemical formula and MS/MS fragmentation pattern as the standard compound (section 2.1) measured in a parallel analysis in the same analytical conditions. The metabolites identified at level 2 in our results displayed an MS/MS or UV spectrum in accordance with the bibliography. The metabolites annotated as compounds known to be produced by $P$. verrucosum and presenting coherent MS/MS spectra were identified at the level 3A. The metabolites annotated as compounds never characterized on $P$. verrucosum and presenting coherent MS/MS spectra were identified at the level 3B. Complementary in silico fragmentations were performed using CFM-ID [33] and compared with experimental MS/MS spectra of annotated metabolites of level 3.

A molecular network generated using GNPS [34] was created from MS/MS spectra in the CID mode of all annotated secondary metabolites. The software parameters were set as follows: ion mass tolerance= $0.0036 \mathrm{Da}$, cosine score $=0.7$, minimum match fragment ion $=1$, maximum connected components $=100$ and Top-K=100, filter peaks removed. The resulting molecular network was visualized in Cytoscape 2.8.2 [35].

\section{Results and Discussion}

\subsection{Certification of Penicillium verrucosum}

The identification of fungal strains could be problematic for secondary metabolome studies due to the lack of robust classification criteria [20], despite the availability of genetic classification. For example, species such as Penicillium nordicum and P. verrucosum were considered as Penicillium viridicatum for some time and some of their secondary metabolites are still referenced as $P$. viridicatum compounds, therefore misleading studies on these fungi. Given the confusion between these similar fungi, it was 
crucial for our study to ensure the identification of $P$. verrucosum. Three different approaches were investigated. Firstly, a morphological characterization was achieved and displayed both macroscopic and microscopic Penicillium properties, namely terverticillate conidiophores, rough-walled and globose conidia. At this stage, no differentiation could be made between $P$. verrucosum and $P$. nordicum as these two species display the same characteristics. Then, cultures on YES agar were performed and showed a red-brown reverse color characteristic of $P$. verrucosum under some sporulation areas. This observation is the only morphological point enabling differentiation between $P$. verrucosum and $P$. nordicum [29]. Secondly, the fungal secondary metabolite analysis achieved by HPLC-HRMS led to the identification of ochratoxin A and citrinin, which were validated by comparison with the standards. Ochratoxin A is known to be produced by both $P$. nordicum and $P$. verrucosum but, according to the Penicillium classification of Larsen et al. [20], only $P$. verrucosum is known to produce citrinin in addition to ochratoxin A. Finally, a genetic identification was conducted. Since Samson et al. [36] estimated that $\beta$-tubulin sequences are relevant species markers, we compared the $\beta$-tubulin DNA sequences of the studied fungus with the standard sequences of $P$. verrucosum and $P$. nordicum. As a result, $\beta$-tubulin sequences showed strong similarities with those of $P$. verrucosum. ITS DNA sequences are well-conserved sequences also used as species markers in fungal studies. Comparison of the ITS sequences confirmed the strong similarity between the studied strain (NRRL 5571) and the standard sequences of $P$. verrucosum. To conclude, the three identification steps (morphological observations, metabolite characterizations and genetic validation) were in accordance with the identification of $P$. verrucosum. NRRL 5571 was also classified as $P$. verrucosum by Larsen et al. in a study characterizing 48 P. verrucosum strains [20].

\subsection{HPLC-HRMS Analysis of the Three Wheat Cultures}

The characterization of the fungal secondary metabolome was carried out according to the protocol previously developed in our group [28]. Natural wheat, ${ }^{13} \mathrm{C}$ wheat and ${ }^{13} \mathrm{C}^{15} \mathrm{~N}$ wheat were infected with P. verrucosum under adapted culture conditions (i.e. culture in the dark at $25^{\circ} \mathrm{C}$ for 30 days). A control sample, corresponding to non-infected natural wheat, was placed in the same environment. The secondary 
metabolites were then extracted and the samples analyzed separately by HPLC-HRMS. The extracts were not pooled in order to limit the complexity of MS spectra due to the complex isotopic compositions used in our protocol and to avoid possible overlapping signals despite the high-resolution power provided by the Orbitrap analyzer. The total ion current chromatograms obtained in the positive and negative ionization modes are presented in Figure 1. First, the chromatogram and mass spectrum obtained from the ${ }^{13} \mathrm{C}^{15} \mathrm{~N}$ labeling experiment were analyzed to specifically detect all the secondary metabolites. The isotopic labeling with $50 \%{ }^{13} \mathrm{C}$ and $100 \%{ }^{15} \mathrm{~N}$ provides an easily recognizable signal, since it generates a specific ion pattern corresponding to a normal distribution of ${ }^{12} \mathrm{C} /{ }^{13} \mathrm{C}$ on the mass spectrum (Figure $2 \mathrm{C}$ ). These specific signals could be exclusively attributed to either the labeled substrate or the fungal metabolites, enabling the removal of any contaminant or chemical used during incubation or extraction. Here, 91 and 130 specific isotopic patterns were detected by positive (ESI+) and negative (ESI-) electrospray ionization modes respectively. Among these signals, 33 adducts and in-source fragment ions were rejected in the ESI+ mode (68 were rejected for the ESI - mode) in order to consider only molecular ions for each secondary metabolite [37]. This led to a final listing of 58 signals in the positive ionization mode and 62 in the negative mode. The same approach was applied to the ${ }^{13} \mathrm{C}$ labeling experiment, in which secondary metabolites displayed another specific pattern (Figure 2B) due to the 3\% of remaining ${ }^{12} \mathrm{C}$. For each previously detected ${ }^{13} \mathrm{C}^{15} \mathrm{~N}$ labeled ions, the ${ }^{13} \mathrm{C}$ equivalent signal was found in HRMS spectra. Each secondary metabolite was finally searched in the HRMS spectra obtained from the natural ${ }^{12} \mathrm{C}$ experiment (Figure 2A). To validate the detection of similar metabolites in the three parallel HPLCHRMS analyses $\left({ }^{12} \mathrm{C},{ }^{13} \mathrm{C}\right.$ and $\left.{ }^{13} \mathrm{C}^{15} \mathrm{~N}\right)$, chromatographic retention times and MS/MS spectra were compared. As displayed in Figure 2, MS/MS spectra were conducted on precursor ions detected at the same retention time (26.7 min in the example given in Figure 2), evidencing that the same metabolite was detected in the three labeled substrates. Finally, wheat molecules were rejected by comparing extract and control samples. In this way, 3 and 13 compounds were eliminated from the ESI+ and ESI - results, respectively. A final list of the 98 secondary metabolites detected from $P$. verrucosum is reported in Table 1. The metabolites detected both in ESI+ and ESI- are displayed as a single entry in Table 1. 
For further identification of the detected metabolites, the first step was the determination of their chemical formulas. Each secondary metabolite, measured $m / z$ in ${ }^{12} \mathrm{C},{ }^{13} \mathrm{C}$ and ${ }^{13} \mathrm{C}^{15} \mathrm{~N}$ extracts was compared using MassCompare, a software developed in-house. This tool calculates all the possible chemical formulas for each ${ }^{12} \mathrm{C},{ }^{13} \mathrm{C}$ and ${ }^{13} \mathrm{C}^{15} \mathrm{~N}$ metabolites, selects the common ones, and calculates the number of carbon and nitrogen atoms by subtractions between ${ }^{12} \mathrm{C},{ }^{13} \mathrm{C}$ and ${ }^{13} \mathrm{C}^{15} \mathrm{~N} \mathrm{~m} / z$ values. In this way, MassCompare provides the unique chemical formula of each metabolite. Concerning the example illustrated in Figure 2, the mass difference between the $\mathrm{m} / \mathrm{z}$ ratio of the ${ }^{12} \mathrm{C}$ ion $(\mathrm{m} / \mathrm{z} 370.1285)$ and the ${ }^{13} \mathrm{C}$-labeled ion $(\mathrm{m} / \mathrm{z} 390.1951)$ was used to determine the number of carbon atoms $\left(\mathrm{n}_{\mathrm{C}}=20\right)$. The mass differences between the $m / z$ of the ${ }^{12} \mathrm{C}$ ion, the ${ }^{13} \mathrm{C}$-labeled ion and the ${ }^{13} \mathrm{C} /{ }^{15} \mathrm{~N}$-labeled ion $(\mathrm{m} / \mathrm{z}$ 382.1667) enabled the calculation of the number of nitrogen atoms $\left(\mathrm{n}_{\mathrm{N}}=1\right)$ by MassCompare. With this information, the software determined a single chemical formula per metabolite $\left(\mathrm{C}_{20} \mathrm{H}_{19} \mathrm{O}_{6} \mathrm{~N}\right.$ for the example of Figure 2). As displayed in Table 1, the metabolite formulas are almost homogenous in terms of heteroatom composition with a majority of oxygenated structures, and only seven non-oxygenated metabolites. Over half of the 98 metabolites contain at least one nitrogen atom. These observations were in agreement with the general composition of fungal secondary metabolites. These extrolites are synthesized by two major types of enzymes. The first, polyketide synthases (PKS), synthesize secondary metabolites from acetyl or malonyl groups to generate oxygenated compounds [38]. The second, nonribosomal peptide-synthetases (NRPS) ensure the incorporation of amino acids, leading to the synthesis of nitrogenous secondary metabolites. Among all detected metabolites, only three display other heteroatoms: one chlorinated and two sulfured formulas. The chlorinated compound was identified as the well-known ochratoxin A. To the best of our knowledge, it is the first time that sulfur containing metabolites has been detected in $P$. verrucosum.

\subsection{Dereplication of Known Secondary Metabolites}

Experimental MS/MS spectra were compared with the open-access GNPS library of natural products [34]. In this study, only one match was found but the MS/MS spectra were not sufficiently similar 
to allow its identification. Alternatively, the database of natural compounds Antibase (2012) [39], coupled with the literature on fungal secondary metabolites, was used to successfully annotate several compounds according to their chemical formulas.

Ochratoxin A (compound 1 in Figure 3 ) is considered as the major toxin of $P$. verrucosum involved in the sanitary and economic troubles caused by this fungus [40,41]. This metabolite was suspected to be detected at $32.4 \mathrm{~min}$ at $\mathrm{m} / \mathrm{z} 404.0897$ with a chlorinated isotopic pattern after positive ionization of the ${ }^{12} \mathrm{C}$ sample. Separate observation of the ${ }^{12} \mathrm{C}$ spectrum, with consideration of the chlorine atom, led to eight possibilities of chemical formulas using the nitrogen rules. The comparison of the three lists of possible formulas from the three different wheat cultures and calculation of the number of carbon and nitrogen atoms finally led to a unique chemical formula: $\mathrm{C}_{20} \mathrm{H}_{19} \mathrm{O}_{6} \mathrm{NCl}$. This result was confirmed by corresponding data obtained in the negative mode. The comparison of chromatographic and MS/MS patterns of the metabolite with those of the standard of ochratoxin A validated the identification at level 1 [32] (see section 2.7). Similarly, analysis of the standard of citrinin, a well-known P. verrucosum metabolite (compound 3 in Figure 3) [20,42], confirmed its production by the studied strain. Ochratoxin B (compound 2 in Figure 3) was also identified at a level $1\left(\mathrm{C}_{20} \mathrm{H}_{20} \mathrm{O}_{6} \mathrm{~N}\right)$ at $\mathrm{R}_{\mathrm{T}}=26.7 \mathrm{~min}$, in accord with other works which noticed the excretion of this dechlorinated intermediate of the biosynthesis pathway of ochratoxin A by P. verrucosum [20,29]. Cyclopiazonic acid, never observed in P. verrucosum, was proposed for annotation of the metabolite $\mathrm{C}_{20} \mathrm{H}_{20} \mathrm{O}_{3} \mathrm{~N}_{2}$ but the chromatographic and MS/MS results obtained from the reference compound ruled out this hypothesis.

Since many natural products are unavailable as reference compounds [37], some secondary metabolites already known to be produced by $P$. verrucosum were detected without it being possible to validate their identifications. The quinazolines verrucine A (compound 6 in Figure 3) [20,43], verrucine B (compound 7 in Figure 3) [20,43] and verrucine F (compound 9 in Figure 3) [44] were annotated. Their MS/MS spectra displayed a loss of ammonia and a consecutive loss of carbon monoxide in accordance with the structures of verrucines A, B and F. Furthermore, the fragmentation patterns of verrucines A and 
B have already been reported [43], allowing the identification of verrucines A and B at a level 2. Since standards were not available, in silico fragmentations were also performed using CFM-ID [33]. Although it should not be considered as proof of identification, this innovative tool provides relevant supporting information. The comparison between experimental and simulated MS/MS spectra is shown in Figure 4A for the formally identified ochratoxin B as an example of successful simulation. Application of CFM-ID to the putative quinazoline structures showed that in silico spectra were in accord with the annotation of the three verrucines. Indeed, the same two major fragment ions at $m / z 360.2$ and $\mathrm{m} / z 332.2$ were detected in both experimental and in silico MS/MS spectra of verrucines A and B (Figure 4B). The same result was obtained with the annotated verrucine $\mathrm{F}(\mathrm{m} / \mathrm{z} 375.1450)$, which shared two fragment ions at $\mathrm{m} / \mathrm{z} 358.2$ and $m / z 330.2$ with the simulated MS/MS spectrum (Figure 4C). Verrucolone, also known as arabenoic acid (compound 5 in Figure 3) and referenced as a typical $P$. verrucosum metabolite [45], was attributed to the detected $\mathrm{C}_{6} \mathrm{H}_{10} \mathrm{O}_{4}$ formula. The experimental MS/MS spectrum was compared to CFM-ID simulations and some common fragment ions were observed at $m / z$ 129.0, 117.0, 115.0 and 103.0. Verrucine F and verrucolone were therefore identified with a level 3A (see section 2.7).

Some secondary metabolites detected in our extracts have already been characterized in Penicillium fungi but not in the $P$. verrucosum strain. Unfortunately, no standards of these supposed secondary metabolites were available. In this case, the only supporting information came from the MS/MS or UV spectra available from the literature and from comparison with in silico fragmentations. Anacine (compound 8 in Figure 3) is known to be produced by Penicillium nordicum, one of the closest fungi of P. verrucosum [20]. This compound is a quinazoline belonging to the verrucines family [46]. In this study, anacine was identified at a level 2 since its UV spectrum was in accordance with the spectrum from literature [43]. Moreover, the unsaturated analog of anacine, namely aurantiomide C (compound 10 in Figure 3) was proposed for the annotation of $\mathrm{C}_{18} \mathrm{H}_{21} \mathrm{O}_{3} \mathrm{~N}_{4}$. To our knowledge, this secondary metabolite was characterized in Penicillium aurantiogriseum [47] but never in P. verrucosum. Although its MS/MS spectrum was not available in literature, an in silico simulation was performed and compared with the experimental MS/MS fragmentation. Both spectra displayed a major fragment ion at $\mathrm{m} / \mathrm{z} 324.1$. In the 
same way, brevianamide F (compound 11 in Figure 3), a metabolite of Penicillium brevicompactum [39] and a precursor of fumitremorgins in Aspergillus fumigatus [48], was proposed for the annotation of $\mathrm{C}_{16} \mathrm{H}_{17} \mathrm{O}_{2} \mathrm{~N}_{3}$. In this case again, no MS/MS information was available in the literature, and the in silico MS/MS simulation displayed almost all the fragment ions observed on the experimental spectrum. LLP880 $\beta$ (compound 4 in Figure 3), another Penicillium metabolite whose fragmentation pattern was not published, was suspected based on database researches [39]. This pestalotin analog, also named hydroxypestalotin, was reported to be synthesized by Penicillium sp. without any precision about the species [39]. Moreover, in a study of the pestalotins family, Rahbaek et al. reported that PC-2, LL-P880 $\gamma$ and two verrucosapyrones displaying very similar structures, were secreted by several strains of $P$. verrucosum [45]. Consequently, $P$. verrucosum likely forms part of the Penicillium species able to produce LL-P880 $\beta$. Finally, several cyclic tetrapeptides of the fungisporin family were suspected to be produced by $P$. verrucosum. Indeed, the metabolite $\mathrm{C}_{28} \mathrm{H}_{36} \mathrm{O}_{6} \mathrm{~N}_{4}$ showed a fragmentation pattern in accordance with a tetrapeptide structure and was identified as fungisporin $\mathrm{C}$ (compound 12 in Figure 3). This natural compound was previously described by Klitgaard et al. in Aspergillus nidulans but the study did not report the fragmentation spectrum [49]. Furthermore, the degradation products of fungisporin A (compound 13 in Figure 3), fungisporin B (compound 14 in Figure 3), fungisporin D (compound 15 in Figure 3) and cyclo-(Tyr-Trp-Val-Val) (compound 16 in Figure 3) were observed. The MS/MS spectrum of the degradation products of fungisporin A was presented by Ali et al. in their study characterizing fungisporins in Penicillium chrysogenum [50]. It was therefore possible to identify at a level 2 the compound 13 (Table 1) as a hydrolysis product of fungisporin A.

\subsection{Unknown Secondary Metabolites}

Finally, 85 formulas could not be associated with known Penicillium secondary metabolites. This observation is in accord with the estimation based on genomic data claiming that more than $80 \%$ of fungal secondary metabolomes remain uncharacterized [11]. All detected secondary metabolites are listed in Table 1 with their structural hypotheses. Moreover, detailed lists of the major MS/MS fragment ions 
generated from each secondary metabolite by higher energy collision dissociation (HCD) (Table 2) as well as by collision-induced dissociation (CID) (Table S1, supplementary data) are provided together with their relative intensity. This complementary information is presented as an argument for further studies into these secondary metabolites. CID and HCD modes provide complementary information useful for structural analyses of fungal secondary metabolites. The resonant excitation mode used in CID within the linear ion trap rarely leads to consecutive fragmentations, whereas the non-resonant excitation of HCD could generate this kind of informative fragmentations. On the other hand, the CID mode is useful to study the filiation between the fragment ions formed in the consecutive $\mathrm{MS}^{\mathrm{n}}$ experiments. Unlike CID, the HCD mode is carried out without the low mass cut-off restriction, allowing the detection of low mass fragment ions.

In Table 1, several metabolites, including those identified, present the same chemical formula but are detected at different retention times. Since two isomers may display very different structures, MS/MS experiments were carried out. Two metabolites with the chemical formula $\mathrm{C}_{18} \mathrm{H}_{20} \mathrm{~N}_{4} \mathrm{O}_{3}$ were detected in the positive ionization mode (Table 1: PVer_341.16_20.1 and PVer_341.16_15.1). This formula was annotated as aurantiomide $\mathrm{C}$ (compound 10 in Figure 3), and the two isomers displayed very similar MS/MS spectra (three same fragment ions in similar relative abundances, Table 2). Similarly, two isomers of $\mathrm{C}_{18} \mathrm{H}_{22} \mathrm{~N}_{4} \mathrm{O}_{3}$ with very similar MS/MS spectra and UV spectra (data not shown) (Table 2) were detected in positive ionization mode and annotated as anacine (compound 8 in Figure 3) (Table 1: PVer_343.17_12.7 and PVer_343.17_17.9).

Conversely, several metabolites with different molecular weights may share a common structure. For example, $\mathrm{C}_{6} \mathrm{H}_{10} \mathrm{O}_{4}$, annotated by Antibase as verrucolone (PVer_147.06_3.1), and $\mathrm{C}_{6} \mathrm{H}_{8} \mathrm{O}_{3}$ (PVer_129.05_7.6) shared three common ions observed in their MS/MS spectra (Table 2), including two specific fragmentations: $m / z=97.0280$ and $m / z=87.0437$. The metabolite $\mathrm{C}_{6} \mathrm{H}_{8} \mathrm{O}_{3}$ (PVer_129.05_7.6) was therefore suspected to be a dehydroxylated form of verrucolone. 
To overcome the complex manual comparison of hundreds of fragmentation patterns, some bioinformatics tools are available, such as MS2LDA [51] or the GNPS Molecular Networking system [34] which was developed for the study of natural products. This latter system highlights ions according to the similarity of their MS/MS spectra. In this way, a molecular network was generated from the MS/MS spectra of all annotated secondary metabolites (Figure 5). This network displays already detected similar compounds such as ochatoxins A and B, or isomers, and ions linked through non-specific neutral losses: $\mathrm{H}_{2} \mathrm{O}$ between ochratoxin $\mathrm{B}$ and the node 299.09 or NH3 and CO between verrucines and the node 391.14. The other groups consist of unknown molecules with the same formula.

More interestingly, the two metabolites at $m / z=511.29$ shared seven common ions, suggesting a high similarity. The corresponding fragmentation patterns were scrutinized to explain the structural differences between the compound at $\mathrm{R}_{\mathrm{T}}=18.0$, annotated as the hydrolyzed fungisporin $\mathrm{A}$, and the metabolite at $\mathrm{R}_{\mathrm{T}}=18.7$. The MS/MS spectra of the two metabolites are shown in Figure $6 . \mathrm{MS}^{3}$ and $\mathrm{MS}^{4}$ experiments were performed to validate that the common ions displayed the same structure, and to obtain more structural information (Figure S2). Both the MS/MS fragmentation patterns of the two metabolites show a dipole ion at $m / z 247.1435$ and $m / z 265.1539$ and consecutive losses of 99 and 147 . Thus, it was suggested that $m / z=247.1435$ consisted of a valine and a phenylalanine residue at the $\mathrm{N}$-terminal extremity (Figure 6, ions $\mathrm{b}_{2}$ ) and that the $\mathrm{m} / \mathrm{z} 265.1539$ consisted of a valine and a phenylalanine residue in the C-terminal extremity of the two peptides (Figure 6, ions $\mathrm{y}_{2}$ ). Moreover, the $\mathrm{MS}^{3}$ spectrum of the $m / z 265$ fragment ion of hydrolyzed fungisporin A showed a $m / z 118.0860\left(\mathrm{C}_{5} \mathrm{H}_{12} \mathrm{NO}_{2}\right)$ corresponding to a C-terminal valine (Figure S2 A), whereas the same $\mathrm{MS}^{3}$ of PVer_511.29_18.7 displayed a $\mathrm{m} / \mathrm{z}$ 166.0860 suggesting a C-terminal phenylalanine (Figure S2 B). This was confirmed by the presence of a fragment ion at $m / z 346.2113$ on its $\mathrm{MS}^{2}$ spectrum (Figure 6, ion $\mathrm{b}_{3}$ ). Finally, the $\mathrm{MS}^{3}$ spectra of the $m / z 247.1435$ fragment ion of both hydrolyzed fungisporin A and PVer_511.29_18.7 were perfectly similar, suggesting that the N-terminal extremities of the two metabolites are identical. In this way, the linear tetrapeptide Val-Phe-Phe-Val was confirmed at $\mathrm{R}_{\mathrm{T}}=18.0 \mathrm{~min}$. According to Ali et al., this molecule is suspected to result from the hydrolysis of a cyclic tetrapeptide, namely fungisporin A. Furthermore, structural analyses 
allowed the identification of its isomer detected at $\mathrm{R}_{\mathrm{T}}=18.7 \mathrm{~min}$ as the tetrapeptide Val-Phe-Val-Phe. Based on the assumption that this linear compound also resulted from the hydrolysis of a cyclic peptide [50], a cyclic Val-Phe-Val-Phe structure was suspected.

\subsection{Conclusion}

The use of two isotope labelings of fungal substrate and HPLC-HRMS analyses enabled the detection of 98 secondary metabolites produced by $P$. verrucosum grown on wheat grains, and led to the unambiguous determination of all their chemical formulas. Among these metabolites, 18 structural hypotheses were proposed from databases, at least nine of which were observed for the first time in $P$. verrucosum: anacine, aurantiomide $\mathrm{C}$, brevianamide F, LL-P880 $\beta$ and at least six fungisporins. The lack of available reference compounds remains problematic for natural product studies. This can be partially balanced by using informatics tools for the simulation of fragmentation spectra. In this study, CFM-ID was successfully used for several $P$. verrucosum metabolites, providing relevant supporting information about the metabolite annotations. However, 79 secondary metabolites remained unidentified. A molecular network was generated with the GNPS system, enabling the detection of a metabolite of interest. This new metabolite was characterized by $\mathrm{MS}^{\mathrm{n}}$ experiments as a linear tetrapeptide, most likely resulting from the hydrolysis of the cyclic Val-Phe-Val-Phe. In any case, the 98 metabolites detected in this study constitute a valuable source of information for further works focused on identification of new metabolites. These data will be useful for purification and structural analyses with the help of complementary analyses by NMR for example, for application to the particular $P$. verrucosum metabolome, or more generally to other Penicillium metabolomes. 


\section{Acknowledgements}

The label substrates were produced by the Groupe de Recherches Appliquées en Phytotechnologie, CEA, IBEB, Cadarache, FR 13108 Saint-Paul-les-Durance, France. The authors are grateful to Andrew Morris who corrected the manuscript. The authors also are grateful to Pascal Bourdaudhui, who developed the software MassCompare, and to Jean-Claude Tabet for his kind help with the mass spectrometry analyses and data monitoring. The authors would also like to thank the French National Infrastructure of Metabolomics and Fluxomics (MetaboHUB-ANR-11-INBS-0010) for their support.

\section{Funding Sources}

This study was co-funded by INRA and French Minister of Higher Education and Research in the context of a project supported by French National Agency of Research (ANR-15-CE21-0010-21 Newmyco). 


\section{References}

[1] A.A. Brakhage, Regulation of fungal secondary metabolism, Nat. Rev. Microbiol. 11 (2013) 21 32.

[2] R. Hare, W. Florey, A.D. Gardner, N.G. Heatley, M.A. Jennings, J. Orr-Ewing, A.G. Sanders, E.P. Abraham, E. Chain, C.M. Fletcher, H.W. Florey, New light on the history of penicillin, Med. Hist. 26 (1982) 1-24.

[3] A.A. Brakhage, V. Schroeckh, Fungal secondary metabolites - Strategies to activate silent gene clusters, Fungal Genet. Biol. 48 (2011) 15-22.

[4] C. Bömke, B. Tudzynski, Diversity, regulation, and evolution of the gibberellin biosynthetic pathway in fungi compared to plants and bacteria, Phytochemistry. 70 (2009) 1876-1893.

[5] J. Avalos, A. Prado-Cabrero, A. Estrada, Neurosporaxanthin production by Neurospora and Fusarium, in: J.-L. Barredo (Ed.), Microb. Carotenoids from Fungi Methods Protoc., Springer S, New York 2012, 2012: pp. 153-159.

[6] T. Kuiper-Goodman, Toxicology Letters risk assessment, Toxicol. Lett. 82/83 (1995) 853-859.

[7] D.L. Eaton, E.P. Gallagher, Mechanisms of aflatoxin carcinogenesis, Annu. Rev. Pharmacol. Toxicol. 34 (1994) 135-172.

[8] T.R. Bui-Klimke, F. Wu, Ochratoxin A and human health risk: A review of the evidence, Crit. Rev. Food Sci. Nutr. 55 (2015) 1860-1869.

[9] A. Zinedine, J.M. Soriano, J.C. Moltó, J. Mañes, Review on the toxicity, occurrence, metabolism, detoxification, regulations and intake of zearalenone: An oestrogenic mycotoxin, Food Chem. Toxicol. 45 (2007) 1-18.

[10] J.W. Bennett, M. Klich, Mycotoxins, Clin. Microbiol. Rev. 16 (2003) 497-516.

[11] E.M. Fox, B.J. Howlett, Secondary metabolism: Regulation and role in fungal biology, Curr. Opin. Microbiol. 11 (2008) 481-487. of Penicillium verrucosum using substrate isotopic labeling and high-resolution mass 
[12] S. Elmholt, P.H. Rasmussen, Penicillium verrucosum occurrence and ochratoxin A contents in organically cultivated grain with special reference to ancient wheat types and drying practice, Mycopathologia. 159 (2005) 421-432.

[13] N. Magan, R. Hope, V. Cairns, D. Aldred, Post-harvest fungal ecology: Impact of fungal growth and mycotoxin accumulation in stored grain, Eur. J. Plant Pathol. 109 (2003) 723-730.

[14] F. Wu, T. Bui-Klimke, K. Naumoff Shields, Potential economic and health impacts of ochratoxin A regulatory standards, World Mycotoxin J. 7 (2014) 387-398.

[15] T. Kuiper-Goodman, P.M. Scott, Risk assessment of the mycotoxin ochratoxin A, Biomed. Environ. Sci. 2 (1989) 179-248.

[16] International Agency for Research on Cancer (IARC), Ochratoxin A, IARC Monogr. Eval. Carcinog. Risk Chem. to Humans. 56 (1993) 489-521.

[17] P. Kroghl, B. Haidt, R. Pleftinas, S. Ceovic, Balkan (endemic) nephropathy and foodborn ochratoxin A: Preliminary results of a survey of foodstuffs, Acta Path. Microbiol. Scand. Sect. B. 85 (1977) 238-240.

[18] F. Malir, V. Ostry, A. Pfohl-Leszkowicz, J. Malir, J. Toman, Ochratoxin A: 50 years of research, Toxins (Basel). 8 (2016) 12-15.

[19] T. Bui-Klimke, F. Wu, Evaluating weight of evidence in the mystery of balkan endemic nephropathy, Risk Anal. 34 (2014) 1688-1705.

[20] T.O. Larsen, A. Svendsen, J. Smedsgaard, Biochemical characterization of ochratoxin A-producing strains of the genus Penicillium, Appl. Environ. Microbiol. 67 (2001) 3630-3635.

[21] M.T. Henke, N.L. Kelleher, Modern mass spectrometry for synthetic biology and structure-based discovery of natural products, Nat. Prod. Rep. 33 (2016) 942-950.

[22] W.B. Dunn, A. Erban, R.J.M. Weber, D.J. Creek, M. Brown, R. Breitling, T. Hankemeier, R. Goodacre, S. Neumann, J. Kopka, M.R. Viant, Mass appeal: Metabolite identification in mass 
spectrometry-focused untargeted metabolomics, Metabolomics. 9 (2013) 44-66.

[23] C. Bueschl, R. Krska, B. Kluger, R. Schuhmacher, Isotopic labeling-assisted metabolomics using LC-MS, Anal. Bioanal. Chem. 405 (2013) 27-33.

[24] C. Bueschl, B. Kluger, M. Lemmens, G. Adam, G. Wiesenberger, V. Maschietto, A. Marocco, J. Strauss, S. Bödi, G.G. Thallinger, R. Krska, R. Schuhmacher, A novel stable isotope labelling assisted workflow for improved untargeted LC-HRMS based metabolomics research, Metabolomics. 10 (2014) 754-769.

[25] N.K.N. Neumann, S.M. Lehner, B. Kluger, C. Bueschl, K. Sedelmaier, M. Lemmens, R. Krska, R. Schuhmacher, Automated LC-HRMS(/MS) approach for the annotation of fragment ions derived from stable isotope labeling-assisted untargeted metabolomics, Anal. Chem. 86 (2014) 7320-7327.

[26] H.B. Bode, B. Bethe, R. Hofs, A. Zeeck, Big effects from small changes: Possible ways to explore nature's chemical diversity, ChemBioChem. 3 (2002) 619-627.

[27] M. Hallas-Moller, K.F. Nielsen, J.C. Frisvad, Influence of the medium and preferred cereal substrate on secondary metabolite production by species from Penicillium series Viridicata, Planta Med. 82 (2016) S1-S381.

[28] P.M. Cano, E.L. Jamin, S. Tadrist, P. Bourdaud'Hui, M. Péan, L. Debrauwer, I.P. Oswald, M. Delaforge, O. Puel, New untargeted metabolic profiling combining mass spectrometry and isotopic labeling: Application on Aspergillus fumigatus grown on wheat, Anal. Chem. 85 (2013) 8412 8420.

[29] J.C. Frisvad, R.A. Samson, Polyphasic taxonomy of Penicillium subgenus Penicillium: A guide to identification of food and air-borne terverticillate Penicillia and their mycotoxins, Stud. Mycol. 49 (2002) 1-173.

[30] Y.C.S. Adjovi, S. Bailly, B.J.G. Gnonlonfin, S. Tadrist, A. Querin, A. Sanni, I.P. Oswald, O. Puel, J.D. Bailly, Analysis of the contrast between natural occurrence of toxigenic Aspergilli of the Flavi 
section and aflatoxin B1 in cassava, Food Microbiol. 38 (2014) 151-159.

[31] M. Pean, S. Boiry, J.-C. Ferrandi, F. Gibiat, O. Puel, M. Delaforge, Production and use of mycotoxins uniformly enriched with stable isotopes for their dosage in biological samples: (1) Production of uniformly enriched biomass, J. Label. Compd. Radiopharm. 50 (2007) 563-564.

[32] L.W. Sumner, A. Amberg, D. Barrett, M.H. Beale, R. Beger, C.A. Daykin, T.W. Fan, O. Fiehn, R. Goodacre, J.L. Griffin, T. Hankemeier, N. Hardy, J. Harnly, Proposed minimum reporting standards for chemical analysis Chemical Analysis Working Group (CAWG) Metabolomics Standards Initiative (MSI), NIH. 3 (2007) 211-221.

[33] F. Allen, A. Pon, M. Wilson, R. Greiner, D. Wishart, CFM-ID: A web server for annotation, spectrum prediction and metabolite identification from tandem mass spectra, Nucleic Acids Res. $42(2014) 1-6$.

[34] M. Wang, J.J. Carver, V. V Phelan, L.M. Sanchez, N. Garg, Y. Peng, D.D. Nguyen, J. Watrous, C.A. Kapono, T. Luzzatto-Knaan, C. Porto, A. Bouslimani, A. V Melnik, M.J. Meehan, W.-T. Liu, M. Crüsemann, P.D. Boudreau, E. Esquenazi, M. Sandoval-Calderón, R.D. Kersten, L.A. Pace, R.A. Quinn, K.R. Duncan, C.-C. Hsu, D.J. Floros, R.G. Gavilan, K. Kleigrewe, T. Northen, R.J. Dutton, D. Parrot, E.E. Carlson, B. Aigle, C.F. Michelsen, L. Jelsbak, C. Sohlenkamp, P. Pevzner, A. Edlund, J. McLean, J. Piel, B.T. Murphy, L. Gerwick, C.-C. Liaw, Y.-L. Yang, H.-U. Humpf, M. Maansson, R.A. Keyzers, A.C. Sims, A.R. Johnson, A.M. Sidebottom, B.E. Sedio, A. Klitgaard, C.B. Larson, C.A. Boya P, D. Torres-Mendoza, D.J. Gonzalez, D.B. Silva, L.M. Marques, D.P. Demarque, E. Pociute, E.C. O’Neill, E. Briand, E.J.N. Helfrich, E.A. Granatosky, E. Glukhov, F. Ryffel, H. Houson, H. Mohimani, J.J. Kharbush, Y. Zeng, J.A. Vorholt, K.L. Kurita, P. Charusanti, K.L. McPhail, K.F. Nielsen, L. Vuong, M. Elfeki, M.F. Traxler, N. Engene, N. Koyama, O.B. Vining, R. Baric, R.R. Silva, S.J. Mascuch, S. Tomasi, S. Jenkins, V. Macherla, T. Hoffman, V. Agarwal, P.G. Williams, J. Dai, R. Neupane, J. Gurr, A.M.C. Rodríguez, A. Lamsa, C. Zhang, K. Dorrestein, B.M. Duggan, J. Almaliti, P.-M. Allard, P. Phapale, L.-F. Nothias, T. Alexandrov, M. 
Litaudon, J.-L. Wolfender, J.E. Kyle, T.O. Metz, T. Peryea, D.-T. Nguyen, D. VanLeer, P. Shinn, A. Jadhav, R. Müller, K.M. Waters, W. Shi, X. Liu, L. Zhang, R. Knight, P.R. Jensen, B.Ø. Palsson, K. Pogliano, R.G. Linington, M. Gutiérrez, N.P. Lopes, W.H. Gerwick, B.S. Moore, P.C. Dorrestein, N. Bandeira, Sharing and community curation of mass spectrometry data with Global Natural Products Social Molecular Networking, Nat. Biotechnol. 34 (2016) 828-837.

[35] P. Shannon, A. Markiel, O. Ozier, N.S. Baliga, J.T. Wang, D. Ramage, N. Amin, B. Schwikowski, T. Ideker, Cytoscape: a software environment for integrated models of biomolecular interaction networks, Genome Res. 13 (2003) 2498-2504.

[36] R.A. Samson, K.A. Seifert, A.F.. Kuijpers, J.A.M.. Houbraken, J.C. Frisvad, Phylogenetic analysis of Penicillium subgenus Penicillium using partial $\beta$-tubulin sequence, Stud. Mycol. 49 (2004) 175200.

[37] K.F. Nielsen, T.O. Larsen, N. Keller, T.S. Bugni, The importance of mass spectrometric dereplication in fungal secondary metabolite analysis, Front. Microbiol. 6 (2015) 71.

[38] Y.H. Chooi, Y. Tang, Navigating the fungal polyketide chemical space: From genes to molecules, J. Org. Chem. 77 (2012) 9933-9953.

[39] H. Laatsch, Antibase 2012: The natural compound identifier, (2012). https://application.wileyvch.de/stmdata/antibase.php (accessed January 2, 2017).

[40] S.C. Duarte, A. Pena, C.M. Lino, A review on ochratoxin A occurrence and effects of processing of cereal and cereal derived food products, Food Microbiol. 27 (2010) 187-198.

[41] J.C. Frisvad, O. Filtenborg, Classification of terverticillate Penicillia based on profiles of mycotoxins and other secondary metabolites, Appl. Environ. Microbiol. 46 (1983) 1301-1310.

[42] M. Kokkonen, M. Jestoi, A. Rizzo, The effect of substrate on mycotoxin production of selected Penicillium strains, Int. J. Food Microbiol. 99 (2005) 207-214.

[43] T.O. Larsen, H. Franzyk, S.R. Jensen, UV-guided isolation of verrucines A and B, novel of Penicillium verrucosum using substrate isotopic labeling and high-resolution mass 
quinazolines from Penicillium verrucosum structurally related to anacine from Penicillium aurantiogriseum, J. Nat. Prod. 62 (1999) 1578-1580.

[44] S.L. Leong, J. Schnürer, A. Broberg, Verrucine F, a quinazoline from Penicillium verrucosum, J. Nat. Prod. 71 (2008) 1455-1457.

[45] L. Rahbaek, S. Sperry, J.C. Frisvad, T.O. Larsen, PC-2, LL-P888gamma and some novel analogue alpha-pyrones from Penicillium nordicum, P. verrucosum and P. olsonii, Biochem. Syst. Ecol. 31 (2003) 313-317.

[46] J.M. Boyes-Korkis, K.A. Gurney, J. Penn, P.G. Mantle, J.N. Bilton, R.N. Sheppard, Anacine, a new benzodiazepine metabolite of Penicillium aurantiogriseum produced with other alkaloids in submerged fermentation, J. Nat. Prod. 56 (1993) 1707-1717.

[47] Z.H. Xin, Y. Fang, L. Du, T. Zhu, L. Duan, J. Chen, Q.Q. Gu, W.M. Zhu, Aurantiomides A-C, quinazoline alkaloids from the sponge-derived fungus Penicillium aurantiogriseum SP0-19, J. Nat. Prod. 70 (2007) 853-855.

[48] S. Maiya, A. Grundmann, S.M. Li, G. Turner, The fumitremorgin gene cluster of Aspergillus fumigatus: Identification of a gene encoding brevianamide F synthetase, ChemBioChem. 7 (2006) $1062-1069$.

[49] A. Klitgaard, J.B. Nielsen, R.J.N. Frandsen, M.R. Andersen, K.F. Nielsen, Combining stable isotope labeling and molecular networking for biosynthetic pathway characterization, Anal. Chem. 87 (2015) 6520-6526.

[50] H. Ali, M.I. Ries, P.P. Lankhorst, R.A.M. Van Der Hoeven, O.L. Schouten, M. Noga, T. Hankemeier, N.N.M.E. Van Peij, R.A.L. Bovenberg, R.J. Vreeken, A.J.M. Driessen, A noncanonical NRPS is involved in the synthesis of fungisporin and related hydrophobic cyclic tetrapeptides in Penicillium chrysogenum, PLoS One. 9 (2014) e98212.

[51] J.J.J. van der Hooft, J. Wandy, M.P. Barrett, K.E. V Burgess, S. Rogers, Topic modeling for 
untargeted substructure exploration in metabolomics, Proc. Natl. Acad. Sci. U. S. A. 113 (2016) $13738-13743$. 


\section{FIGURE CAPTIONS}

Fig. 1. Total ion current chromatograms obtained in the positive (A) and negative (B) ionization modes from the extract of wheat grains infected by Penicillium verrucosum.

Fig. 2. Detection of ochratoxin $B$ : mass spectra detected at $R_{T}=26.7$ min after positive ESI-HPLC-MS from extract of Penicillium verrucosum grown (A) on natural $99 \%{ }^{12} \mathrm{C}$ wheat grains, (B) on grains labeled with $97 \%$ of ${ }^{13} \mathrm{C}$ and (C) on grains labeled with $53 \%$ of ${ }^{13} \mathrm{C}$ and $97 \%$ of ${ }^{15} \mathrm{~N}$. Right-hand panels display the corresponding CID MS/MS spectra from culture (D) on natural $99 \%{ }^{12} \mathrm{C}$ wheat grains, (E) on grains labeled with $97 \%$ of ${ }^{13} \mathrm{C}$ and (F) on grains labeled with $53 \%$ of ${ }^{13} \mathrm{C}$ and $97 \%$ of ${ }^{15} \mathrm{~N}$.

Fig. 3. Secondary metabolites identified from Penicillium verrucosum. The chemical formulas were calculated after comparison of the $m / z$ ratios obtained from cultures of $P$. verrucosum in ${ }^{12} \mathrm{C}$ wheat, $97 \%$ ${ }^{13} \mathrm{C}$ wheat and $53 \%{ }^{13} \mathrm{C} / 97 \%{ }^{15} \mathrm{~N}$ wheat. ${ }^{a}$ Identification at level $1,{ }^{b}$ at level $2,{ }^{c}$ at level 3 of compounds known to be produced by $P$. verrucosum, ${ }^{d}$ at level 3 of compounds never characterized in $P$. verrucosum but in other Penicillium species.

Fig. 4. Comparison between experimental MS/MS spectra (ESI ${ }^{+}$high-resolution CID) of three secondary metabolites of Penicillium verrucosum and the simulated MS/MS spectra of their respective structural hypotheses. (A) Successful in silico simulation: experimental MS/MS spectrum of ochratoxin B (upper part) (identified by homology to an authentic standard) and theoretical MS/MS generated by CFM-ID (lower part). (B) MS/MS spectrum obtained from the secondary metabolite $\mathrm{C}_{21} \mathrm{H}_{21} \mathrm{~N}_{4} \mathrm{O}_{3}$ detected at $\mathrm{R}_{\mathrm{T}}=$ 18,4 min (upper part) and in silico fragmentation of verrucines A and B using CFM-ID (lower part). (C) MS/MS spectrum obtained from the secondary metabolite $\mathrm{C}_{21} \mathrm{H}_{19} \mathrm{~N}_{4} \mathrm{O}_{3}$ detected at $\mathrm{R}_{\mathrm{T}}=18,7$ min (upper part) and in silico fragmentation of verrucine F using CFM-ID (lower part).

Fig. 5. Molecular network of the secondary metabolome of Penicillium verrucosum, created with the GNPS software from the targeted MS/MS spectra (ESI ${ }^{+}$high-resolution CID): nodes name: $m / z$ ratio and retention time of the precursor ion, node size: absolute intensity in a logarithmic scale of the precursor ion 
in the HRMS spectrum, black edges: connected MS/MS spectra according to GNPS software, red dotted edges: manually connected isomers which were not detected by GNPS.

Fig. 6. Comparison of the MS/MS spectra (ESI ${ }^{+}$high-resolution CID) of two secondary metabolites produced by Penicillium verrucosum grown on wheat grains. (A) MS/MS spectra of $\mathrm{C}_{28} \mathrm{H}_{38} \mathrm{~N}_{4} \mathrm{O}_{5}$ detected at $\mathrm{R}_{\mathrm{T}}=18.0$ min (PVer_511.29_18.0). (B) MS/MS spectra of $\mathrm{C}_{28} \mathrm{H}_{38} \mathrm{~N}_{4} \mathrm{O}_{5}$ detected at $\mathrm{R}_{\mathrm{T}}=18.7 \mathrm{~min}$ (PVer_511.29_18.7).

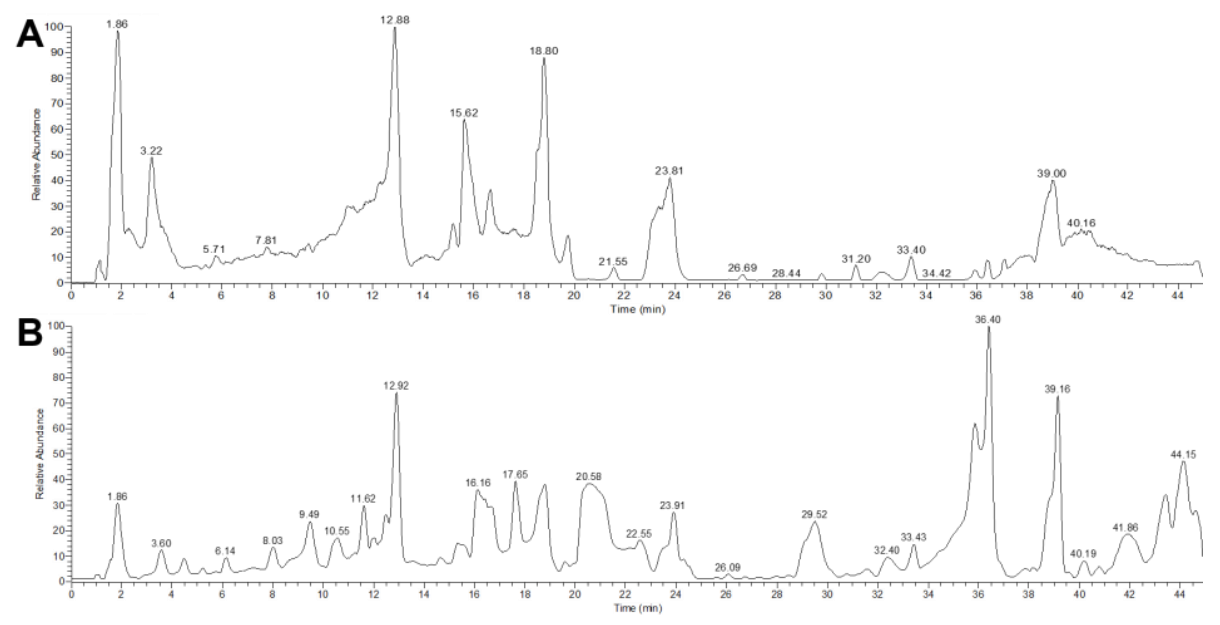



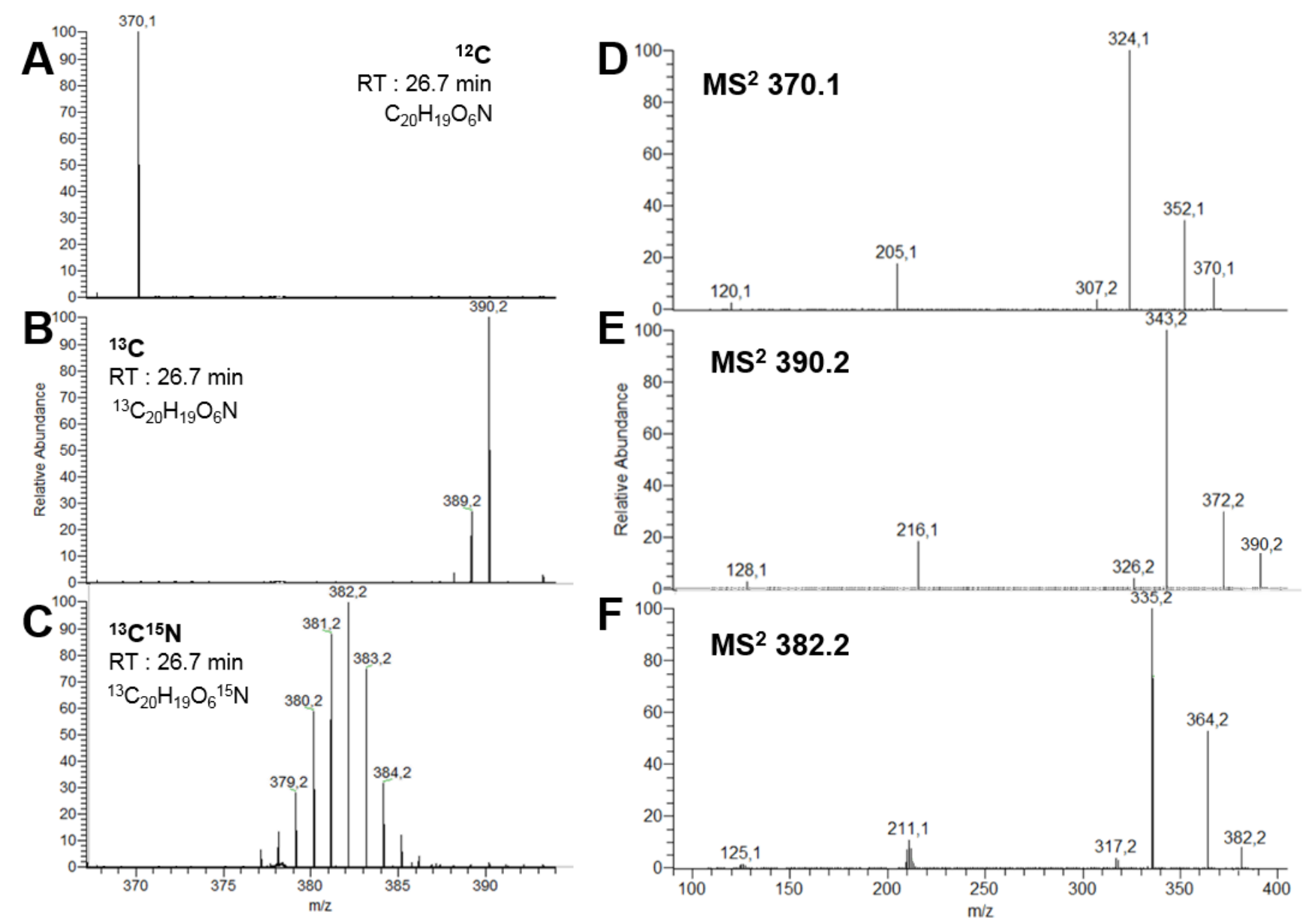

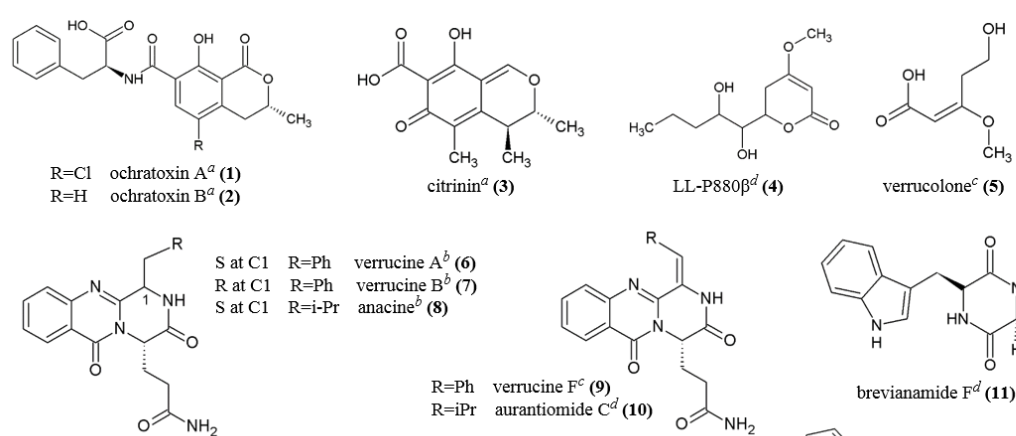

$\mathrm{S}$ at C1 $\quad \mathrm{R}=\mathrm{Ph} \quad$ verrucine $\mathrm{A}^{b}$ (6) $\mathrm{R}$ at $\mathrm{C} 1 \quad \mathrm{R}=\mathrm{Ph} \quad$ verrucine $\mathrm{B}^{b}(7)$ $\mathrm{S}$ at $\mathrm{C} 1 \quad \mathrm{R}=\mathrm{i}-\mathrm{Pr} \quad$ anacine $^{b}(\mathbf{8})$

o $\mathrm{NH}_{2}$
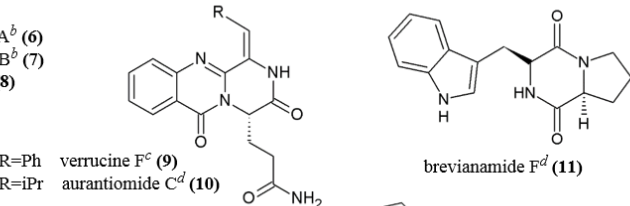

brevianamide $\mathrm{F}^{d}(\mathbf{1 1})$

$\mathrm{R}=\mathrm{iPr}$ aurantiomide $\mathrm{C}^{d}(\mathbf{1 0})$

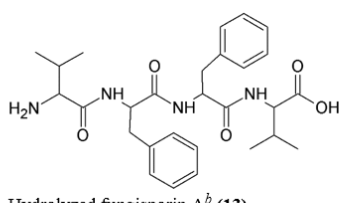

Hydrolyzed fungisporin $\mathrm{A}^{b}$ (13)

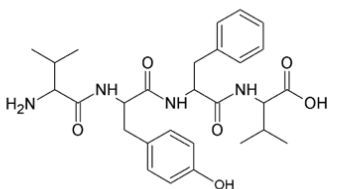

Hydrolyzed fungisporin $\mathrm{B}^{d}$ (14)

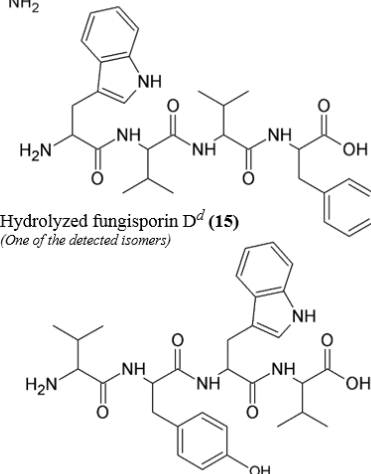

Hydrolyzed cyclo(Tyr-Trp-Val-Val) ${ }^{d}$ (16) 

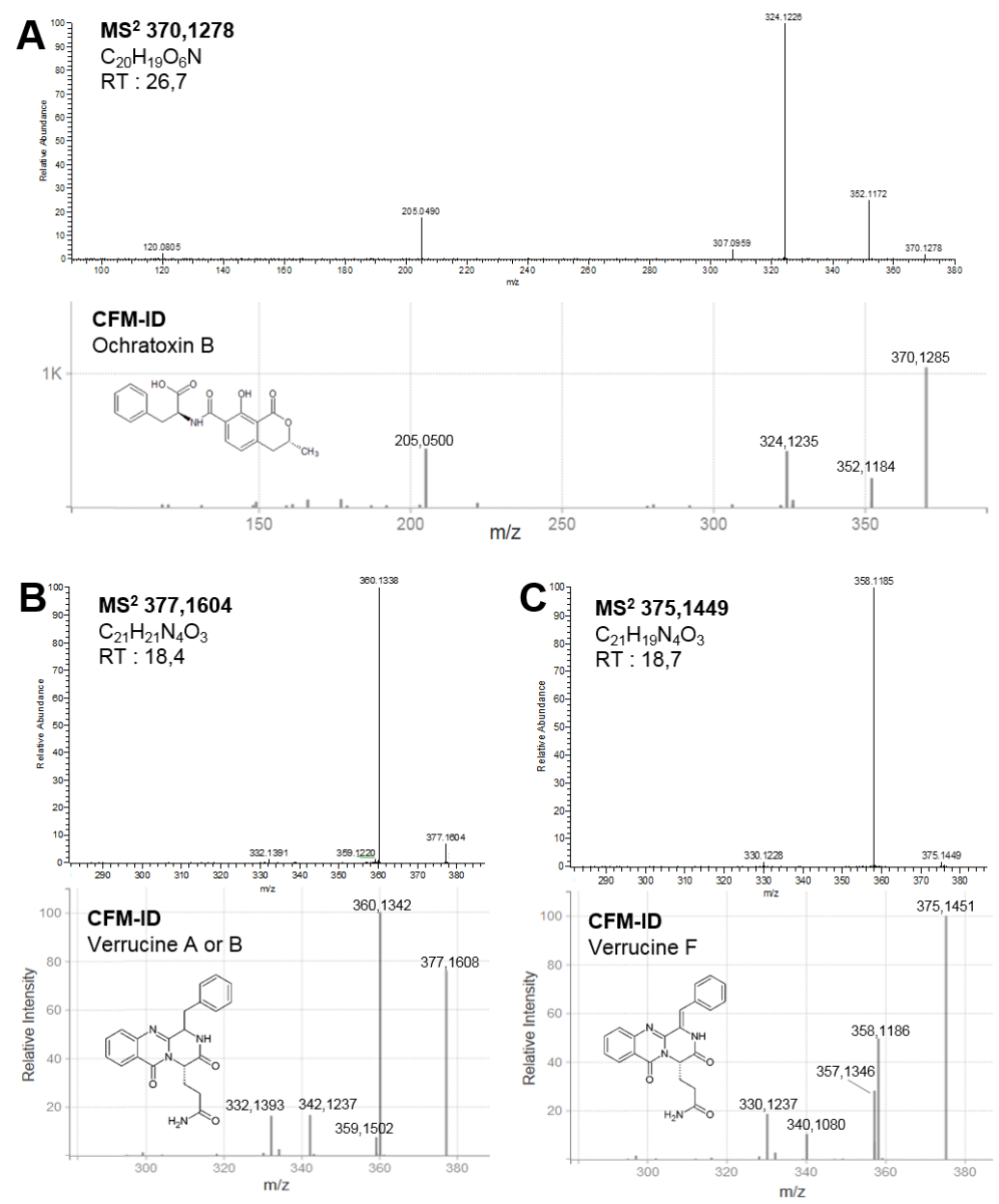

Comment citer ce document :

Hautbergue T Puel, O. (Auteur de correspondance), Tadrist, S., Meneghetti, L., Péan, M.

Delaforge, M., Debrauwer, L., Oswald, I., Jamin, E. L. (2017). Evidencing 98 secondary metabolites of Penicillium verrucosum using substrate isotopic labeling and high-resolution mass 

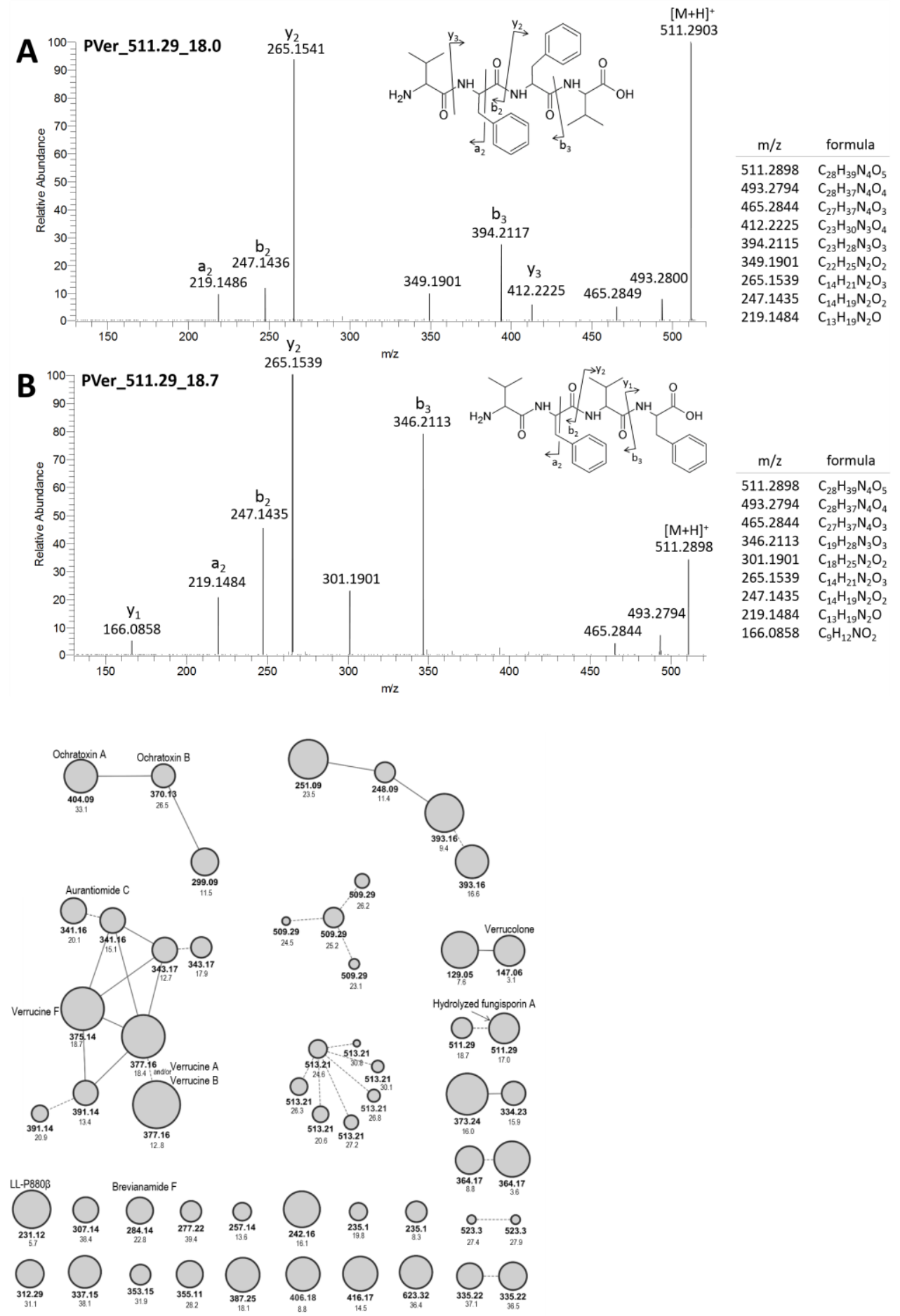


\section{TABLE CAPTIONS}

Table 1. List of the secondary metabolites detected in Penicillium verrucosum grown on wheat grains. ${ }^{a}$ The chemical formulas were calculated after comparison of the $\mathrm{m} / \mathrm{z}$ ratios obtained from the culture of $P$. verrucosum in ${ }^{12} \mathrm{C}$ wheat, $97 \%{ }^{13} \mathrm{C}$ wheat and $53 \%{ }^{13} \mathrm{C} / 96 \%{ }^{15} \mathrm{~N}$ wheat. ${ }^{b}$ Identification at level $1,{ }^{c}$ at level $2,{ }^{d}$ at level 3 of compounds known to be produced by P. verrucosum, ${ }^{e}$ at level 3 of compounds never characterized in P. verrucosum but in other Penicillium species, ${ }^{f}$ secondary metabolites identifier (PVer_m/z_RT).

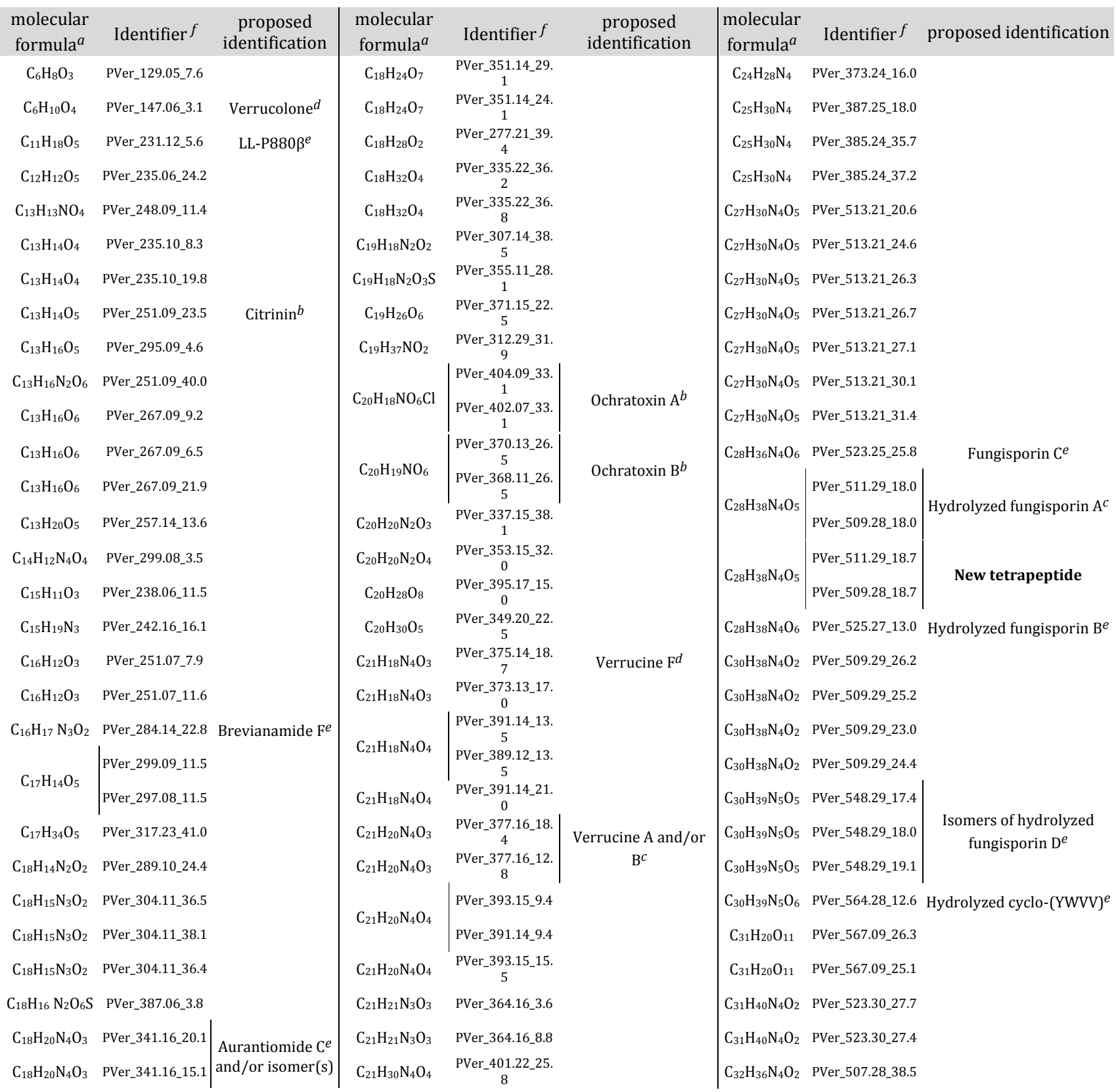




\begin{tabular}{|c|c|c|c|c|}
\hline $\mathrm{C}_{18} \mathrm{H}_{22} \mathrm{~N}_{4} \mathrm{O}_{3}$ & PVer_343.17_12.7 & Anacine $^{c}$ & $\mathrm{C}_{21} \mathrm{H}_{30} \mathrm{~N}_{4} \mathrm{O}_{4}$ & $\begin{array}{c}\text { PVer_401.22_21. } \\
9\end{array}$ \\
\hline $\mathrm{C}_{18} \mathrm{H}_{22} \mathrm{~N}_{4} \mathrm{O}_{3}$ & PVer_343.17_17.9 & and/or isomer(s) & $\mathrm{C}_{22} \mathrm{H}_{27} \mathrm{~N}_{3}$ & $\begin{array}{c}\text { PVer_334.23_15. } \\
8\end{array}$ \\
\hline $\mathrm{C}_{18} \mathrm{H}_{24} \mathrm{O}_{7}$ & PVer_351.14_18.1 & & $\mathrm{C}_{22} \mathrm{H}_{27} \mathrm{~N}_{3}$ & $\begin{array}{c}\text { PVer_332.21_35. } \\
6\end{array}$ \\
\hline $\mathrm{C}_{18} \mathrm{H}_{24} \mathrm{O}_{7}$ & PVer_351.14_29.0 & & $\mathrm{C}_{23} \mathrm{H}_{21} \mathrm{~N}_{5} \mathrm{O}_{3}$ & $\begin{array}{c}\text { PVer_416.17_14. } \\
6\end{array}$ \\
\hline $\mathrm{C}_{18} \mathrm{H}_{24} \mathrm{O}_{7}$ & PVer_351.14_24.6 & & $\mathrm{C}_{23} \mathrm{H}_{23} \mathrm{~N}_{3} \mathrm{O}_{4}$ & PVer_406.17_8.8 \\
\hline
\end{tabular}

\begin{tabular}{|c|c|}
\hline $\mathrm{C}_{32} \mathrm{H}_{42} \mathrm{O}_{7}$ & PVer_537.29_39.5 \\
\hline $\mathrm{C}_{32} \mathrm{H}_{42} \mathrm{O}_{8}$ & PVer_553.28_38.7 \\
\hline $\mathrm{C}_{32} \mathrm{H}_{42} \mathrm{O}_{8}$ & PVer_553.28_38.3 \\
\hline \multirow{2}{*}{$\mathrm{C}_{37} \mathrm{H}_{42} \mathrm{~N}_{4} \mathrm{O}_{5}$} & PVer_623.32_36.3 \\
\hline & PVer_621.30_36.3 \\
\hline $\begin{array}{c}\mathrm{C}_{38} \mathrm{H}_{42} \mathrm{~N}_{4} \mathrm{O}_{1} \\
0\end{array}$ & PVer_7 \\
\hline
\end{tabular}

Comment citer ce document:

Hautbergue, T., Puel, O. (Auteur de correspondance), Tadrist, S., Meneghetti, L., Péan, M.

Delaforge, M., Debrauwer, L., Oswald, I., Jamin, E. L. (2017). Evidencing 98 secondary metabolites of Penicillium verrucosum using substrate isotopic labeling and high-resolution mass 
Table 2. Secondary metabolites detected from Penicillium verrucosum after culture on wheat grains and their MS/MS fragmentation in higher energy collision dissociation (HCD) mode. The fragmentation spectra are presented as a list of fragment ions with their relative intensity. ${ }^{a}$ The chemical formulas were calculated after comparison of the $\mathrm{m} / \mathrm{z}$ ratios obtained from the culture of $P$. verrucosum in ${ }^{12} \mathrm{C}$ wheat, $97 \%{ }^{13} \mathrm{C}$ wheat and $53 \%{ }^{13} \mathrm{C} / 96 \%{ }^{15} \mathrm{~N}$ wheat. ${ }^{b}$ Secondary metabolites identifier $\left(\mathrm{PVer} \_\mathrm{m} / \mathrm{z}_{-} \mathrm{R}_{\mathrm{T}}\right)$. 


\begin{tabular}{|c|c|c|c|c|c|c|}
\hline $\begin{array}{c}\text { Identifie } \\
\mathrm{r} f\end{array}$ & $\begin{array}{c}\text { molecu } \\
\text { lar } \\
\text { formul } \\
\mathrm{a}^{a}\end{array}$ & $\begin{array}{c}\text { paren } \\
\text { tion }\end{array}$ & $\begin{array}{c}{ }^{12} \mathrm{C} \\
m / z \\
(\mathrm{Da})\end{array}$ & $\begin{array}{c}\mathrm{R}_{\mathrm{T}} \\
(\mathrm{min} \\
)\end{array}$ & \begin{tabular}{|c|}
\multicolumn{1}{|c|}{$\begin{array}{c}\text { mode } \\
\text { (Normalize } \\
\text { d Collision } \\
\text { Energy) }\end{array}$} \\
\end{tabular} & $m / z$ of majors fragment ions ( $\%$ relative intensity) \\
\hline $\begin{array}{c}\text { PVer_129.0 } \\
5 \_7.6\end{array}$ & $\mathrm{C}_{6} \mathrm{H}_{8} \mathrm{O}_{3}$ & $\left.\begin{array}{c}{[\mathrm{M}+\mathrm{H}]} \\
+\end{array}\right]$ & $\begin{array}{c}129.0 \\
544\end{array}$ & 7.6 & $\operatorname{HCD}(20)$ & $129.0544(100) 87.0437(12) 97.0281(8) 55.0176(6) 111.0439(3)$ \\
\hline $\begin{array}{c}\text { PVer_147.0 } \\
6 \_3.1\end{array}$ & $\mathrm{C}_{6} \mathrm{H}_{10} \mathrm{O}_{4}$ & $\left.\begin{array}{c}{[\mathrm{M}+\mathrm{H}]} \\
+\end{array}\right]$ & \begin{tabular}{c|c}
147.0 \\
655
\end{tabular} & 3.1 & HCD (20) & $\begin{array}{l}\text { 147.0655(5) 129.0543(100) } 117.0543(32) 97.0280(17) 85.0280(17) 99.0437(7) 87.0437(7) \quad 75.0437(6) \\
55.0176(5) 71.0488(5) 115.0387(3)\end{array}$ \\
\hline \begin{tabular}{c|c} 
PVer_231.1 \\
$2 \_5.6$
\end{tabular} & $\mathrm{C}_{11} \mathrm{H}_{18} \mathrm{O}_{5}$ & $\left.\begin{array}{c}{[\mathrm{M}+\mathrm{H}]} \\
+\end{array}\right]$ & $\begin{array}{c}231.1 \\
229\end{array}$ & 5.6 & $\operatorname{HCD}(20)$ & \begin{tabular}{|lllllll}
$231.1227(100)$ & $181.0857(70)$ & $127.0387(27)$ & $213.1120(26)$ & $195.1014(25)$ & $81.0332(22)$ & $139.0750(21)$ \\
$155.1064(21) 141.0543(13) 151.1116(10)$ & & & & \\
\end{tabular} \\
\hline $\begin{array}{c}\text { PVer_235.0 } \\
6 \_24.2\end{array}$ & $\mathrm{C}_{12} \mathrm{H}_{12} \mathrm{O}_{5}$ & {$[\mathrm{M}-\mathrm{H}]^{-}$} & $\begin{array}{c}235.0 \\
616\end{array}$ & 24.2 & $\operatorname{HCD}(60)$ & $235.0616(100) 217.0510(85) 191.0718(70) 163.0770(5) 189.0562(2)$ \\
\hline $\begin{array}{c}\text { PVer_248.0 } \\
9 \_11.4\end{array}$ & \begin{tabular}{|c|}
$\mathrm{C}_{13} \mathrm{H}_{13} \mathrm{~N}$ \\
$\mathrm{O}_{4}$ \\
\end{tabular} & $\begin{array}{c}{[\mathrm{M}+\mathrm{H}]} \\
+\end{array}$ & $\begin{array}{c}248.0 \\
916\end{array}$ & 11.4 & HCD (20) & $248.0914(100) 230.0810(87)$ \\
\hline $\begin{array}{c}\text { PVer_235.1 } \\
0 \_8.3\end{array}$ & $\mathrm{C}_{13} \mathrm{H}_{14} \mathrm{O}_{4}$ & $\begin{array}{c}{[\mathrm{M}+\mathrm{H}]} \\
+\end{array}$ & $\begin{array}{l}235.0 \\
965\end{array}$ & 8.3 & HCD (20) & $235.0964(100) 217.0687(2) 191.0699(2)$ \\
\hline $\begin{array}{c}\text { PVer_235.1 } \\
0 \_19.8\end{array}$ & $\mathrm{C}_{13} \mathrm{H}_{14} \mathrm{O}_{4}$ & $\begin{array}{c}{[\mathrm{M}+\mathrm{H}]} \\
+\end{array}$ & $\begin{array}{c}235.0 \\
965 \\
\end{array}$ & 19.8 & HCD (20) & $235.0963(47) 193.0855(100) 165.0907(7) 217.0854(6) 207.1014(4) 139.1114(4) 211.0958(2)$ 137.0955(3) \\
\hline $\begin{array}{c}\text { PVer_251.0 } \\
\text { 9_23.5 }\end{array}$ & $\mathrm{C}_{13} \mathrm{H}_{14} \mathrm{O}_{5}$ & $\begin{array}{c}{[\mathrm{M}+\mathrm{H}]} \\
+\end{array}$ & $\begin{array}{c}251.0 \\
912\end{array}$ & 23.5 & HCD (20) & $251.0915(100) 233.0807(45)$ \\
\hline $\begin{array}{c}\text { PVer_295.0 } \\
9 \_4.6\end{array}$ & $\begin{array}{c}\mathrm{C}_{13} \mathrm{H}_{16} \mathrm{~N}_{2} \\
\mathrm{O}_{6}\end{array}$ & {$[\mathrm{M}-\mathrm{H}]$} & $\begin{array}{c}295.0 \\
936\end{array}$ & 4.6 & $\operatorname{HCD}(60)$ & $\begin{array}{l}\text { 295.0936(15) 221.0573(100) 251.1039(20) 236.0807(7) 193.0622(25) 249.0885(6) 122.0252(9) 137.0361(9) } \\
208.0859(8)\end{array}$ \\
\hline $\begin{array}{c}\text { PVer_251.0 } \\
9 \_40.0\end{array}$ & $\mathrm{C}_{13} \mathrm{H}_{16} \mathrm{O}_{5}$ & {$[\mathrm{M}-\mathrm{H}]$} & $\begin{array}{c}251.0 \\
924\end{array}$ & 40.0 & $\operatorname{HCD}(60)$ & $251.0924(100) 233.0823(9) 163.0769(9) 189.0562(5) 207.1030(6)$ \\
\hline $\begin{array}{c}\text { PVer_267.0 } \\
9 \_9.2\end{array}$ & $\mathrm{C}_{13} \mathrm{H}_{16} \mathrm{O}_{6}$ & {$[\mathrm{M}-\mathrm{H}]^{-}$} & \begin{tabular}{c|c|c|c|c|}
267.0 \\
871
\end{tabular} & 9.2 & $\operatorname{HCD}(60)$ & $267.0871(100) 249.0772(6) 207.0666(16) 163.0769(5) 193.0875(4) 237.0773(3) 205.0875(2)$ \\
\hline $\begin{array}{c}\text { PVer_267.0 } \\
9 \_6.5\end{array}$ & $\mathrm{C}_{13} \mathrm{H}_{16} \mathrm{O}_{6}$ & {$[\mathrm{M}-\mathrm{H}]^{-}$} & $\begin{array}{c}267.0 \\
871\end{array}$ & 6.5 & $\operatorname{HCD}(60)$ & $267.0871(100) 239.0721(5) 249.0563(1)$ \\
\hline $\begin{array}{c}\text { PVer_267.0 } \\
\text { 9_21.9 }\end{array}$ & $\mathrm{C}_{13} \mathrm{H}_{16} \mathrm{O}_{6}$ & {$[\mathrm{M}-\mathrm{H}]^{-}$} & $\begin{array}{c}267.0 \\
871\end{array}$ & 21.9 & $\operatorname{HCD}(60)$ & 267.0871(95) 221.0825(100) 249.0773(10) 177.0926(10) 203.0719(4) \\
\hline $\begin{array}{c}\text { PVer_257.1 } \\
4 \_13.6\end{array}$ & $\mathrm{C}_{13} \mathrm{H}_{20} \mathrm{O}_{5}$ & {$\left[\begin{array}{c}\mathrm{M}+\mathrm{H}] \\
+\end{array}\right]$} & $\begin{array}{c}257.1 \\
381\end{array}$ & 13.6 & $\operatorname{HCD}(35)$ & $257.1382(65) 157.0493(100)$ \\
\hline $\begin{array}{c}\text { PVer_299.0 } \\
8 \_3.5 \\
\end{array}$ & \begin{tabular}{|c|}
$\mathrm{C}_{14} \mathrm{H}_{12} \mathrm{~N}_{4}$ \\
$\mathrm{O}_{4}$ \\
\end{tabular} & {$[\mathrm{M}-\mathrm{H}]^{-}$} & \begin{tabular}{|c|}
299.0 \\
783 \\
\end{tabular} & 3.5 & $\operatorname{HCD}(60)$ & $299.0783(35) 256.0731(100) 228.0421(15) 145.0413(30$ ) 213.0673(5) 238.0627(3) 185.0361(3) \\
\hline $\begin{array}{c}\text { PVer_238.0 } \\
6 \_11.5\end{array}$ & $\mathrm{C}_{15} \mathrm{H}_{11} \mathrm{O}_{3}$ & {$[\mathrm{M}-\mathrm{H}]^{-}$} & $\begin{array}{c}238.0 \\
640\end{array}$ & 11.5 & $\operatorname{HCD}(60)$ & $238.0637(100) 210.0694(2)$ \\
\hline $\begin{array}{c}\text { PVer_242.1 } \\
6 \_16.1\end{array}$ & $\mathrm{C}_{15} \mathrm{H}_{19} \mathrm{~N}_{3}$ & $\left.\begin{array}{c}{[\mathrm{M}+\mathrm{H}]} \\
+\end{array}\right]$ & \begin{tabular}{c|c}
242.1 \\
647
\end{tabular} & 16.1 & $\operatorname{HCD}(20)$ & $242.650(100) 111.0915(33)$ \\
\hline $\begin{array}{c}\text { PVer_251.0 } \\
7 \_7.9\end{array}$ & $\mathrm{C}_{16} \mathrm{H}_{12} \mathrm{O}_{3}$ & {$[\mathrm{M}-\mathrm{H}]$} & \begin{tabular}{c|c}
251.0 \\
712 \\
\end{tabular} & 7.9 & $\operatorname{HCD}(60)$ & $251.0712(100) 250.0646(13) 223.0771(6) 211.0405(4)$ \\
\hline $\begin{array}{c}\text { PVer_251.0 } \\
7 \_11.6\end{array}$ & $\mathrm{C}_{16} \mathrm{H}_{12} \mathrm{O}_{3}$ & {$[\mathrm{M}-\mathrm{H}]$} & \begin{tabular}{c|c|}
251.0 \\
712 \\
\end{tabular} & 11.6 & $\operatorname{HCD}(60)$ & $251.0712(100) 233.0612(3) 223.0770(2)$ \\
\hline \begin{tabular}{c|c} 
PVer_284.1 \\
$4 \_22.8$
\end{tabular} & $\begin{array}{c}\mathrm{C}_{16} \mathrm{H}_{17} \mathrm{~N}_{3} \\
\mathrm{O}_{2}\end{array}$ & $\left.\begin{array}{c}{[\mathrm{M}+\mathrm{H}]} \\
+\end{array}\right]$ & $\begin{array}{c}284.1 \\
388\end{array}$ & 22.8 & HCD (20) & $284.1390(100) 130.0648(30) 170.0597(3) 132.0804(3)$ \\
\hline $\begin{array}{c}\text { PVer_299.0 } \\
\text { 9_11.5 }\end{array}$ & \multirow{2}{*}{$\mathrm{C}_{17} \mathrm{H}_{14} \mathrm{O}_{5}$} & $\left.\begin{array}{c}{[\mathrm{M}+\mathrm{H}]} \\
+\end{array}\right]$ & \begin{tabular}{c|c}
299.0 \\
907 \\
\end{tabular} & \multirow{2}{*}{11.5} & HCD (20) & $\begin{array}{l}\text { 299.0912(60) 205.0493(100) 281.0807(6) 189.0543(6) 253.0857(3) 107.0490(3) 187.0388(3) 159.0438(1) } \\
263.0702(1)\end{array}$ \\
\hline $\begin{array}{c}\text { PVer_297.0 } \\
8 \_11.5\end{array}$ & & {$[\mathrm{M}-\mathrm{H}]$} & \begin{tabular}{c|c}
297.0 \\
773
\end{tabular} & & $\operatorname{HCD}(60)$ & $297.0773(10) 253.08874(100) 238.0641(6) 159.0456(4) 109.0300(4) 93.0350(4) 226.0626(2)$ \\
\hline $\begin{array}{c}\text { PVer_317.2 } \\
3 \_41.0\end{array}$ & $\mathrm{C}_{17} \mathrm{H}_{34} \mathrm{O}_{5}$ & {$[\mathrm{M}-\mathrm{H}]^{-}$} & 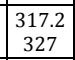 & 41.0 & $\operatorname{HCD}(60)$ & $\begin{array}{l}\text { 317.2327(100) 257.2127(52) 299.2229(6) 115.0770(3) 59.0143(18) 183.1395(4) 195.1759(4) 255.2334(4) } \\
85.0663(1)\end{array}$ \\
\hline $\begin{array}{c}\text { PVer_289.1 } \\
0 \_24.4\end{array}$ & $\begin{array}{c}\mathrm{C}_{18} \mathrm{H}_{14} \mathrm{~N}_{2} \\
\mathrm{O}_{2} \\
\end{array}$ & {$[\mathrm{M}-\mathrm{H}]^{-}$} & $\begin{array}{c}289.0 \\
977\end{array}$ & 24.4 & $\operatorname{HCD}(60)$ & $289.0977(100) 116.0510(33) 261.1039(24)$ \\
\hline $\begin{array}{c}\text { PVer_304.1 } \\
1 \_36.5\end{array}$ & $\begin{array}{c}\mathrm{C}_{18} \mathrm{H}_{15} \mathrm{~N}_{3} \\
\mathrm{O}_{2}\end{array}$ & {$[\mathrm{M}-\mathrm{H}]$} & $\begin{array}{c}304.1 \\
087\end{array}$ & 36.5 & $\operatorname{HCD}(60)$ & $\begin{array}{l}304.1087(26) 213.0549(100) 261.1037(29) 183.0567(8) 286.0988(6) 159.0568(3) 145.0410(3) 212.0470(3) \\
262.0989(3)\end{array}$ \\
\hline $\begin{array}{c}\text { PVer_304.1 } \\
1 \_38.1 \\
\end{array}$ & \begin{tabular}{c|}
$\mathrm{C}_{18} \mathrm{H}_{15} \mathrm{~N}_{3}$ \\
$\mathrm{O}_{2}$ \\
\end{tabular} & {$[\mathrm{M}-\mathrm{H}]$} & $\begin{array}{c}304.1 \\
087\end{array}$ & 38.1 & $\operatorname{HCD}(60)$ & $304.1087(100) 213.0548(100) 261.1038(25) 286.0998(5) 183.0569(7)$ \\
\hline \begin{tabular}{c|c|c|} 
PVer_304.1 \\
$1 \_36.4$ \\
\end{tabular} & \begin{tabular}{c|}
$\mathrm{C}_{18} \mathrm{H}_{15} \mathrm{~N}_{3}$ \\
$\mathrm{O}_{2}$ \\
\end{tabular} & {$[\mathrm{M}-\mathrm{H}]^{-}$} & \begin{tabular}{c|}
304.1 \\
087
\end{tabular} & 36.4 & $\operatorname{HCD}(60)$ & $304.1102(3) 213.0548(100) 261.1040(25) 286.0992(5) 183.0569(7) 159.0569(4)$ \\
\hline $\begin{array}{c}\text { PVer_387.0 } \\
6 \_3.8\end{array}$ & $\begin{array}{c}\mathrm{C}_{18} \mathrm{H}_{16} \mathrm{~N}_{2} \\
\mathrm{O}_{6} \mathrm{~S}\end{array}$ & {$[\mathrm{M}-\mathrm{H}]$} & $\begin{array}{c}387.0 \\
655\end{array}$ & 3.8 & $\operatorname{HCD}(60)$ & \begin{tabular}{|lllllll}
$387.0662(100)$ & $176.0356(75)$ & $353.0784(55)$ & $202.0149(50)$ & $269.0570(52)$ & $121.0296(20)$ & $231.0414(16)$ \\
$277.0297(15)$ & $121.0296(21) 270.0646(16)$ & & & & \\
\end{tabular} \\
\hline 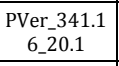 & $\begin{array}{c}\mathrm{C}_{18} \mathrm{H}_{20} \mathrm{~N}_{4} \\
\mathrm{O}_{3} \\
\end{array}$ & $\begin{array}{c}{[\mathrm{M}+\mathrm{H}]} \\
+\end{array}$ & $\begin{array}{c}341.1 \\
604\end{array}$ & 20.1 & HCD (20) & $341.1605(55) 324.1338(100) 296.1389(10)$ \\
\hline $\begin{array}{c}\text { PVer_341.1 } \\
6 \_15.1\end{array}$ & $\begin{array}{c}\mathrm{C}_{18} \mathrm{H}_{20} \mathrm{~N}_{4} \\
\mathrm{O}_{3}\end{array}$ & $\left.\begin{array}{c}{[\mathrm{M}+\mathrm{H}]} \\
+\end{array}\right]$ & $\begin{array}{c}341.1 \\
604\end{array}$ & 15.1 & HCD (20) & $341.1601(60) 324.1337(100) 296.1388(8) 151.1114(2) 195.1013(1)$ \\
\hline $\begin{array}{c}\text { PVer_343.1 } \\
7 \_12.7 \\
\end{array}$ & \begin{tabular}{c|}
$\mathrm{C}_{18} \mathrm{H}_{22} \mathrm{~N}_{4}$ \\
$\mathrm{O}_{3}$ \\
\end{tabular} & $\left.\begin{array}{c}{[\mathrm{M}+\mathrm{H}]} \\
+\end{array}\right]$ & \begin{tabular}{|c|}
343.1 \\
747
\end{tabular} & 12.7 & $\operatorname{HCD}(20)$ & $343.1758(45) 326.1496(100) 298.1546(5)$ \\
\hline $\begin{array}{c}\text { PVer_343.1 } \\
7 \_17.9 \\
\end{array}$ & $\begin{array}{c}\mathrm{C}_{18} \mathrm{H}_{22} \mathrm{~N}_{4} \\
\mathrm{O}_{3} \\
\end{array}$ & $\left.\begin{array}{c}{[\mathrm{M}+\mathrm{H}]} \\
+\end{array}\right]$ & \begin{tabular}{c|}
343.1 \\
747 \\
\end{tabular} & 17.9 & HCD (20) & $343.1758(45) 326.1495(100) 298.1545(5) 270.0869(2)$ \\
\hline \begin{tabular}{c|c} 
PVer_351.1 \\
$4 \_18.1$
\end{tabular} & $\mathrm{C}_{18} \mathrm{H}_{24} \mathrm{O}_{7}$ & {$[\mathrm{M}-\mathrm{H}]^{-}$} & 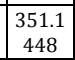 & 18.1 & $\operatorname{HCD}(60)$ & $351.1448(100) 307.1190(60$ ) 249.0773(60) 333.1351(9) 205.0874(11) 101.0248(4) 219.1028(3) \\
\hline \begin{tabular}{c|c} 
PVer_351.1 \\
$4 \_29.0$
\end{tabular} & $\mathrm{C}_{18} \mathrm{H}_{24} \mathrm{O}_{7}$ & {$[\mathrm{M}-\mathrm{H}]^{-}$} & 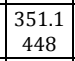 & 29.0 & $\operatorname{HCD}(60)$ & \begin{tabular}{|lllllll}
$351.1450(65)$ & $201.0924(100)$ & $245.1188(80)$ & $277.1449(42)$ & $263.1293(21)$ & $231.1033(21)$ & $233.1188(19)$ \\
$213.0923(6)$
\end{tabular} \\
\hline $\begin{array}{c}\text { PVer_351.1 } \\
4 \_24.6\end{array}$ & $\mathrm{C}_{18} \mathrm{H}_{24} \mathrm{O}_{7}$ & {$[\mathrm{M}-\mathrm{H}]^{-}$} & \begin{tabular}{|l|}
351.1 \\
448 \\
\end{tabular} & 24.6 & $\operatorname{HCD}(60)$ & $351.1448(55) 321.1347(100) 307.1190(55) 245.0825(40$ ) 201.0924(35) 233.1186(5) 259.0980(5) \\
\hline $\begin{array}{c}\text { PVer_351.1 } \\
4 \_29.1 \\
\end{array}$ & $\mathrm{C}_{18} \mathrm{H}_{24} \mathrm{O}_{7}$ & {$[\mathrm{M}-\mathrm{H}]$} & \begin{tabular}{|l|}
351.1 \\
448 \\
\end{tabular} & 29.1 & $\operatorname{HCD}(60)$ & $351.1448(60) 201.0925(100) 245.1189(80) 277.1448(45)$ \\
\hline $\begin{array}{c}\text { PVer_351.1 } \\
4 \_24.1 \\
\end{array}$ & $\mathrm{C}_{18} \mathrm{H}_{24} \mathrm{O}_{7}$ & {$[\mathrm{M}-\mathrm{H}]^{-}$} & $\begin{array}{c}351.1 \\
448 \\
\end{array}$ & 24.1 & $\operatorname{HCD}(60)$ & $351.1450(100) 321.1349(45) 249.0773(30) 307.1191(25) 245.0826(18) 201.0924(17) 101.0614(19)$ \\
\hline $\begin{array}{c}\text { PVer_277.2 } \\
1 \_39.4\end{array}$ & $\mathrm{C}_{18} \mathrm{H}_{28} \mathrm{O}_{2}$ & $\begin{array}{c}{[\mathrm{M}+\mathrm{H}]} \\
+\end{array}$ & $\begin{array}{c}277.2 \\
158 \\
\end{array}$ & 39.4 & HCD (20) & $277.2164(100) 179.1431(12) 135.1168(5) 259.2060(3) 121.1011(3) 235.1696(1) 161.1325(1)$ \\
\hline $\begin{array}{c}\text { PVer_335.2 } \\
2 \_36.2\end{array}$ & $\mathrm{C}_{18} \mathrm{H}_{32} \mathrm{O}_{4}$ & $\begin{array}{c}{[\mathrm{M}+\mathrm{Na}} \\
]^{+}\end{array}$ & \begin{tabular}{|c|}
335.2 \\
187
\end{tabular} & 36.2 & $\operatorname{HCD}(35)$ & $335.2187(100) 317.2079(3) 190.1235(3)$ \\
\hline $\begin{array}{c}\text { PVer_335.2 } \\
\text { 2_36.8 }\end{array}$ & $\mathrm{C}_{18} \mathrm{H}_{32} \mathrm{O}_{4}$ & $\begin{array}{c}{[\mathrm{M}+\mathrm{Na}} \\
]^{+}\end{array}$ & $\begin{array}{c}335.2 \\
187\end{array}$ & 36.8 & $\operatorname{HCD}(35)$ & $335.2187(100) 190.1232(20)$ \\
\hline $\begin{array}{c}\text { PVer_307.1 } \\
4 \_38.5\end{array}$ & $\begin{array}{c}\mathrm{C}_{19} \mathrm{H}_{18} \mathrm{~N}_{2} \\
\mathrm{O}_{2}\end{array}$ & $\begin{array}{c}{[\mathrm{M}+\mathrm{H}]} \\
+\end{array}$ & $\begin{array}{l}307.1 \\
427\end{array}$ & 38.5 & $\operatorname{HCD}(35)$ & $307.1439(75) 229.0971(100) 201.1022(12) 111.0553(10) 292.1207(2)$ \\
\hline
\end{tabular}




\begin{tabular}{|c|c|c|c|c|c|c|}
\hline \begin{tabular}{c|} 
PVer_355.1 \\
$1 \_28.1$
\end{tabular} & $\begin{array}{c}\mathrm{C}_{19} \mathrm{H}_{18} \mathrm{~N}_{2} \\
\mathrm{O}_{3} \mathrm{~S}\end{array}$ & $\left.\begin{array}{c}{[\mathrm{M}+\mathrm{H}]} \\
+\end{array}\right]$ & $\begin{array}{c}355.1 \\
105\end{array}$ & 28.1 & $\operatorname{HCD}(20)$ & \begin{tabular}{|lllllll}
$355.1135(10)$ & $289.0967(100)$ & $337.1000(45)$ & $307.1074(43)$ & $308.1150(32)$ & $279.1125(15)$ & $290.1047(12)$ \\
$236.1068(11)$ & $261.1019(10) 327.1156(10)$ & & & & \\
\end{tabular} \\
\hline $\begin{array}{l}\text { PVer_371.1 } \\
5 \_22.5\end{array}$ & $\mathrm{C}_{19} \mathrm{H}_{26} \mathrm{O}_{6}$ & $\begin{array}{c}{[\mathrm{M}-} \\
2 \mathrm{H}+\mathrm{Na} \\
]\end{array}$ & $\begin{array}{c}371.1 \\
466\end{array}$ & 22.5 & $\operatorname{HCD}(60)$ & $371.1466(100) 353.1375(26)$ \\
\hline $\begin{array}{c}\text { PVer_312.2 } \\
9 \_31.9\end{array}$ & \begin{tabular}{c|}
$\mathrm{C}_{19} \mathrm{H}_{37} \mathrm{~N}$ \\
$\mathrm{O}_{2}$ \\
\end{tabular} & $\begin{array}{c}{[\mathrm{M}+\mathrm{H}]} \\
+\end{array}$ & $\begin{array}{c}312.2 \\
895\end{array}$ & 31.9 & $\mathrm{HCD}(20)$ & $312.2895(5) 294.2792(100) 276.2684(5) 86.0598(5)$ 259.2417(5) 277.2524(1) 264.2683(1) \\
\hline $\begin{array}{c}\text { PVer_404.0 } \\
9 \_33.1 \\
\end{array}$ & \multirow{2}{*}{$\begin{array}{c}\mathrm{C}_{20} \mathrm{H}_{18} \mathrm{~N} \\
\mathrm{O}_{6} \mathrm{Cl}\end{array}$} & $\begin{array}{c}{[\mathrm{M}+\mathrm{H}]} \\
+\end{array}$ & \begin{tabular}{|c|}
404.0 \\
897 \\
\end{tabular} & \multirow{2}{*}{33.1} & $\operatorname{HCD}(20)$ & $404.0892(30) 358.0836(100) 239.0103(66) 341.0572(13) 257.0209(11)$ 120.0804(10) 386.0786(5) \\
\hline $\begin{array}{c}\text { PVer_402.0 } \\
7 \_33.1 \\
\end{array}$ & & {$[\mathrm{M}-\mathrm{H}]^{-}$} & \begin{tabular}{|c|}
402.0 \\
750 \\
\end{tabular} & & $\operatorname{HCD}(60)$ & $402.0756(10) 358.0855(100) 211.0171(42) 254.0229(12) 239.0122(6) 322.1090(6) 314.0587$ (6) 270.0696(4) \\
\hline $\begin{array}{c}\text { PVer_370.1 } \\
\text { 3_26.5 }\end{array}$ & \multirow{2}{*}{$-\begin{array}{c}\mathrm{C}_{20} \mathrm{H}_{19} \mathrm{~N} \\
\mathrm{O}_{6}\end{array}$} & $\begin{array}{c}{[\mathrm{M}+\mathrm{H}]} \\
+\end{array}$ & $\begin{array}{c}370.1 \\
285 \\
\end{array}$ & \multirow{2}{*}{26.5} & $\operatorname{HCD}(20)$ & $370.1286(30) 205.0492(100) 324.1226(37) 352.1172(7) 223.0598(7) 307.0959(6) 120.0805(6)$ \\
\hline $\begin{array}{c}\text { PVer_368.1 } \\
\text { 1_26.5 } \\
\end{array}$ & & {$[\mathrm{M}-\mathrm{H}]^{-}$} & \begin{tabular}{|c|}
368.1 \\
130 \\
\end{tabular} & & $\operatorname{HCD}(60)$ & $368.1146(100) 324.1245(100) 220.0622(15) 177.0561(7) 280.0981(6) 164.0720(4)$ \\
\hline $\begin{array}{c}\text { PVer_337.1 } \\
\text { 5_38.1 }\end{array}$ & $\begin{array}{c}\mathrm{C}_{20} \mathrm{H}_{20} \mathrm{~N}_{2} \\
\mathrm{O}_{3} \\
\end{array}$ & $\begin{array}{c}{[\mathrm{M}+\mathrm{H}]} \\
+\end{array}$ & $\begin{array}{c}337.1 \\
552 \\
\end{array}$ & 38.1 & HCD $(20)$ & $337.1552(100) 306.1360(54) 336.1952(10) 305.1281(7) 277.1331(6) 167.0851(3) 91.0539(4)$ \\
\hline $\begin{array}{c}\text { PVer_353.1 } \\
5 \_32.0\end{array}$ & $\begin{array}{c}\mathrm{C}_{20} \mathrm{H}_{20} \mathrm{~N}_{2} \\
\mathrm{O}_{4} \\
\end{array}$ & $\begin{array}{c}{[\mathrm{M}+\mathrm{H}]} \\
+\end{array}$ & $\begin{array}{c}353.1 \\
480\end{array}$ & 32.0 & $\operatorname{HCD}(20)$ & $353.1489(100) 305.1278(56) 336.1460(7) 118.0409(4) 275.1020(2) 91.0538(1) 322.1309(1)$ \\
\hline $\begin{array}{c}\text { PVer_395.1 } \\
\text { 7_15.0 }\end{array}$ & $\mathrm{C}_{20} \mathrm{H}_{28} \mathrm{O}_{8}$ & {$[\mathrm{M}-\mathrm{H}]^{-}$} & $\begin{array}{c}395.1 \\
708 \\
\end{array}$ & 15.0 & $\operatorname{HCD}(60)$ & \begin{tabular}{|lllllll}
$\begin{array}{l}395.1708(46) \\
245.1553(17)\end{array} 289.1813(9) 137.0612(7)$ & $3496(62)$ & $305.1762(60)$ & $243.1760(36)$ & $287.1656(29)$ & $307.1919(25)$ \\
\end{tabular} \\
\hline $\begin{array}{c}\text { PVer_349.2 } \\
0 \_22.5 \\
\end{array}$ & $\mathrm{C}_{20} \mathrm{H}_{30} \mathrm{O}_{5}$ & {$[\mathrm{M}-\mathrm{H}]^{-}$} & $\begin{array}{c}349.2 \\
012 \\
\end{array}$ & 22.5 & $\operatorname{HCD}(60)$ & $349.2021(9) 305.1761(100) 261.1865(15)$ 137.0612(7) 287.1656(5) \\
\hline \begin{tabular}{c|c} 
PVer_375.1 \\
$4 \_18.7$
\end{tabular} & \begin{tabular}{c|}
$\mathrm{C}_{21} \mathrm{H}_{18} \mathrm{~N}_{4}$ \\
$\mathrm{O}_{3}$
\end{tabular} & $\begin{array}{c}{[\mathrm{M}+\mathrm{H}]} \\
+\end{array}$ & \begin{tabular}{c|c}
375.1 \\
450
\end{tabular} & 18.7 & $\operatorname{HCD}(20)$ & $375.1449(42) 358.1183(100) 330.1231(11)$ \\
\hline $\begin{array}{c}\text { PVer_373.1 } \\
3 \_17.0\end{array}$ & $\begin{array}{c}\mathrm{C}_{21} \mathrm{H}_{18} \mathrm{~N}_{4} \\
\mathrm{O}_{3} \\
\end{array}$ & {$[\mathrm{M}-\mathrm{H}]^{-}$} & \begin{tabular}{c|}
373.1 \\
295
\end{tabular} & 17.0 & $\operatorname{HCD}(60)$ & $373.1304(62) 302.0940(100) 262.0991(8) 145.0413(6) 355.1206(3)$ \\
\hline $\begin{array}{c}\text { PVer_391.1 } \\
4 \_13.5\end{array}$ & \multirow{2}{*}{$-\begin{array}{c}\mathrm{C}_{21} \mathrm{H}_{18} \mathrm{~N}_{4} \\
\mathrm{O}_{4}\end{array}$} & $\begin{array}{c}{[\mathrm{M}+\mathrm{H}]} \\
+\end{array}$ & $\begin{array}{c}391.1 \\
392\end{array}$ & \multirow{2}{*}{13.5} & $\operatorname{HCD}(20)$ & $391.1398(55) 374.1130(100) 346.1182(15)$ \\
\hline $\begin{array}{c}\text { PVer_389.1 } \\
2 \_13.5\end{array}$ & & {$[\mathrm{M}-\mathrm{H}]^{-}$} & \begin{tabular}{|c|}
389.1 \\
258 \\
\end{tabular} & & $\operatorname{HCD}(60)$ & $389.1264(100) 318.0897(99) 83.0145(15) 278.0948(7)$ 145.0417(5) \\
\hline $\begin{array}{c}\text { PVer_391.1 } \\
4 \_21.0\end{array}$ & $\begin{array}{c}\mathrm{C}_{21} \mathrm{H}_{18} \mathrm{~N}_{4} \\
\mathrm{O}_{4}\end{array}$ & $\begin{array}{c}{[\mathrm{M}+\mathrm{H}]} \\
+\end{array}$ & $\begin{array}{c}391.1 \\
392\end{array}$ & 21.0 & $\operatorname{HCD}(20)$ & $391.1396(60) 374.1129(100) 346.1182(10) 149.0230(9) 328.1078(1) 263.0810(1)$ \\
\hline $\begin{array}{c}\text { PVer_377.1 } \\
\text { 6_18.4 }\end{array}$ & $\begin{array}{c}\mathrm{C}_{21} \mathrm{H}_{20} \mathrm{~N}_{4} \\
\mathrm{O}_{3}\end{array}$ & $\begin{array}{c}{[\mathrm{M}+\mathrm{H}]} \\
+\end{array}$ & $\begin{array}{c}377.1 \\
604\end{array}$ & 18.4 & $\operatorname{HCD}(20)$ & 377.1603(45) 360.1336(100) 332.1392(5) 91.0539(1) \\
\hline $\begin{array}{c}\text { PVer_377.1 } \\
\text { 6_12.8 }\end{array}$ & $\begin{array}{c}\mathrm{C}_{21} \mathrm{H}_{20} \mathrm{~N}_{4} \\
\mathrm{O}_{3} \\
\end{array}$ & $\begin{array}{c}{[\mathrm{M}+\mathrm{H}]} \\
+\end{array}$ & $\begin{array}{c}377.1 \\
604 \\
\end{array}$ & 12.8 & $\operatorname{HCD}(20)$ & $377.1603(43) 360.1339(100) 332.1389(5)$ \\
\hline $\begin{array}{c}\text { PVer_393.1 } \\
5 \_9.4\end{array}$ & \multirow{2}{*}{$\mid \begin{array}{c}\mathrm{C}_{21} \mathrm{H}_{20} \mathrm{~N}_{4} \\
\mathrm{O}_{4}\end{array}$} & $\begin{array}{c}{[\mathrm{M}+\mathrm{H}]} \\
+\end{array}$ & $\begin{array}{c}393.1 \\
554 \\
\end{array}$ & \multirow{2}{*}{9.4} & $\operatorname{HCD}(20)$ & $393.1551(18) 358.1181(100) 375.1448(75) 376.1284(55) 330.1227(7)$ 120.0441(6) 274.1180(3) \\
\hline $\begin{array}{c}\text { PVer_391.1 } \\
4 \_9.4\end{array}$ & & {$[\mathrm{M}-\mathrm{H}]^{-}$} & $\begin{array}{c}391.1 \\
400\end{array}$ & & $\operatorname{HCD}(60)$ & $391.1154(100) 250.1088(47) 294.0985(37) 373.1052(22) 300.0863(17) 276.0863(12) 302.0943(12)$ \\
\hline $\begin{array}{c}\text { PVer_393.1 } \\
\text { 5_15.5 }\end{array}$ & $\begin{array}{c}\mathrm{C}_{21} \mathrm{H}_{20} \mathrm{~N}_{4} \\
\mathrm{O}_{4} \\
\end{array}$ & $\begin{array}{c}{[\mathrm{M}+\mathrm{H}]} \\
+\end{array}$ & \begin{tabular}{|c|}
393.1 \\
554
\end{tabular} & 15.5 & HCD $(20)$ & $393.1541(3) 358.1181(100) 375.1447(65) 330.1230(13) 376.1286(7) 348.1341(1)$ \\
\hline $\begin{array}{c}\text { PVer_364.1 } \\
6 \_3.6 \\
\end{array}$ & $\begin{array}{c}\mathrm{C}_{21} \mathrm{H}_{21} \mathrm{~N}_{3} \\
\mathrm{O}_{3} \\
\end{array}$ & $\begin{array}{c}{[\mathrm{M}+\mathrm{H}]} \\
+\end{array}$ & \begin{tabular}{|c|}
364.1 \\
656 \\
\end{tabular} & 3.6 & $\operatorname{HCD}(20)$ & $364.1649(100) 308.1026(10) 200.1066(6) 346.1544(3) 196.1115(2)$ \\
\hline $\begin{array}{c}\text { PVer_364.1 } \\
6 \_8.8 \\
\end{array}$ & \begin{tabular}{c|}
$\mathrm{C}_{21} \mathrm{H}_{21} \mathrm{~N}_{3}$ \\
$\mathrm{O}_{3}$ \\
\end{tabular} & $\begin{array}{c}{[\mathrm{M}+\mathrm{H}]} \\
+\end{array}$ & \begin{tabular}{|c|}
364.1 \\
656 \\
\end{tabular} & 8.8 & $\operatorname{HCD}(20)$ & $364.1650(100) 308.1027(20) 177.0654(3) 200.1067(2) 294.1232(1) 346.1543(1) 145.1280(1)$ \\
\hline $\begin{array}{c}\text { PVer_401.2 } \\
2 \_25.8\end{array}$ & $\begin{array}{c}\mathrm{C}_{21} \mathrm{H}_{30} \mathrm{~N}_{4} \\
\mathrm{O}_{4}\end{array}$ & {$[\mathrm{M}-\mathrm{H}]^{-}$} & \begin{tabular}{c|c}
401.2 \\
185
\end{tabular} & 25.8 & $\operatorname{HCD}(60)$ & 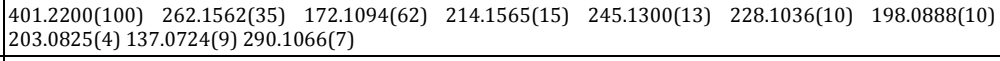 \\
\hline $\begin{array}{c}\text { PVer_401.2 } \\
2 \_21.9\end{array}$ & \begin{tabular}{c|}
$\mathrm{C}_{21} \mathrm{H}_{30} \mathrm{~N}_{4}$ \\
$\mathrm{O}_{4}$
\end{tabular} & {$[\mathrm{M}-\mathrm{H}]^{-}$} & \begin{tabular}{c|c}
401.2 \\
185
\end{tabular} & 21.9 & $\operatorname{HCD}(60)$ & 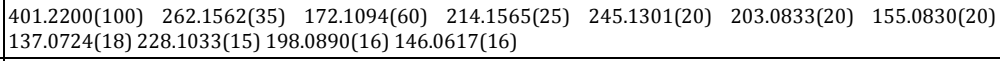 \\
\hline 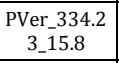 & $\mathrm{C}_{22} \mathrm{H}_{27} \mathrm{~N}_{3}$ & $\begin{array}{c}{[\mathrm{M}+\mathrm{H}]} \\
+\end{array}$ & \begin{tabular}{|c|}
334.2 \\
271 \\
\end{tabular} & 15.8 & HCD $(20)$ & $334.2274(100) 203.1540(55) 217.1696(1)$ \\
\hline $\begin{array}{c}\text { PVer_332.2 } \\
1 \_35.6\end{array}$ & $\mathrm{C}_{22} \mathrm{H}_{27} \mathrm{~N}_{3}$ & {$[\mathrm{M}-\mathrm{H}]^{-}$} & \begin{tabular}{|c|}
332.2 \\
126
\end{tabular} & 35.6 & $\operatorname{HCD}(60)$ & $332.2126(100) 264.1148(10) 240.1504(3)$ \\
\hline $\begin{array}{c}\text { PVer_416.1 } \\
7 \_14.6\end{array}$ & $\begin{array}{c}\mathrm{C}_{23} \mathrm{H}_{21} \mathrm{~N}_{5} \\
\mathrm{O}_{3} \\
\end{array}$ & $\begin{array}{c}{[\mathrm{M}+\mathrm{H}]} \\
+\end{array}$ & $\begin{array}{c}416.1 \\
712\end{array}$ & 14.6 & HCD $(20)$ & $416.1709(40) 399.1445(100) 130.0648(56) 270.0870(45) 287.1136(40) 242.0919(1)$ \\
\hline $\begin{array}{c}\text { PVer_406.1 } \\
7 \_8.8\end{array}$ & $\begin{array}{c}\mathrm{C}_{23} \mathrm{H}_{23} \mathrm{~N}_{3} \\
\mathrm{O}_{4} \\
\end{array}$ & $\begin{array}{c}{[\mathrm{M}+\mathrm{H}]} \\
+\end{array}$ & $\begin{array}{c}406.1 \\
758\end{array}$ & 8.8 & HCD $(20)$ & $406.1753(21) 346.1544(100) 364.1649(62) 306.1232(19) 308.1027(10) 290.0921(4)$ \\
\hline $\begin{array}{c}\text { PVer_373.2 } \\
4 \_16.0\end{array}$ & $\mathrm{C}_{24} \mathrm{H}_{28} \mathrm{~N}_{4}$ & $\begin{array}{c}{[\mathrm{M}+\mathrm{H}]} \\
+\end{array}$ & \begin{tabular}{c|c|}
373.2 \\
385
\end{tabular} & 16.0 & HCD (20) & $373.2381(100) 242.1649(55) 111.0914(7) 256.1802(1)$ \\
\hline \begin{tabular}{c|c|c|} 
PVer_387.2 \\
$5 \_18.0$
\end{tabular} & $\mathrm{C}_{25} \mathrm{H}_{30} \mathrm{~N}_{4}$ & $\left.\begin{array}{c}{[\mathrm{M}+\mathrm{H}]} \\
+\end{array}\right]$ & \begin{tabular}{c|c|}
387.2 \\
536
\end{tabular} & 18.0 & $\operatorname{HCD}(50)$ & $\begin{array}{l}387.2542(3) 130.0652(100) 187.1232(10) 156.0810(10) 72.0807(7) 144.0809(6) 113.1074(4) 257.1889(2) \\
58.0650(2)\end{array}$ \\
\hline $\begin{array}{c}\text { PVer_385.2 } \\
4 \_35.7\end{array}$ & $\mathrm{C}_{25} \mathrm{H}_{30} \mathrm{~N}_{4}$ & {$[\mathrm{M}-\mathrm{H}]^{-}$} & $\begin{array}{c}385.2 \\
391\end{array}$ & 35.7 & $\operatorname{HCD}(60)$ & $385.2404(99) 230.1668(100) 256.2821(65) 116.0508(24) 156.0823(16)$ \\
\hline $\begin{array}{c}\text { PVer_385.2 } \\
4 \_37.2\end{array}$ & $\mathrm{C}_{25} \mathrm{H}_{30} \mathrm{~N}_{4}$ & {$[\mathrm{M}-\mathrm{H}]^{-}$} & $\begin{array}{c}385.2 \\
391\end{array}$ & 37.2 & $\operatorname{HCD}(60)$ & $385.2391(85) 230.1667(100) 256.1822(72) 116.0511(27) 156.0824(25) 142.0667(10)$ \\
\hline $\begin{array}{c}\text { PVer_513.2 } \\
1 \_20.6\end{array}$ & $\begin{array}{c}\mathrm{C}_{27} \mathrm{H}_{30} \mathrm{~N}_{4} \\
\mathrm{O}_{5}\end{array}$ & $\begin{array}{c}{[\mathrm{M}+\mathrm{Na}} \\
]^{+}\end{array}$ & $\begin{array}{c}513.2 \\
119\end{array}$ & 20.6 & $\operatorname{HCD}(20)$ & $513.2129(60) 496.1858(100) 227.1063(25) 351.1674(4)$ \\
\hline $\begin{array}{c}\text { PVer_513.2 } \\
1 \_24.6\end{array}$ & $\begin{array}{c}\mathrm{C}_{27} \mathrm{H}_{30} \mathrm{~N}_{4} \\
\mathrm{O}_{5}\end{array}$ & $\begin{array}{c}{[\mathrm{M}+\mathrm{Na}} \\
]^{+}\end{array}$ & $\begin{array}{c}513.2 \\
119\end{array}$ & 24.6 & HCD $(20)$ & $513.2129(45) 496.1856(100) 468.1894(6)$ \\
\hline $\begin{array}{c}\text { PVer_513.2 } \\
1 \_26.3\end{array}$ & \begin{tabular}{|c|}
$\mathrm{C}_{27} \mathrm{H}_{30} \mathrm{~N}_{4}$ \\
$\mathrm{O}_{5}$
\end{tabular} & $\begin{array}{c}{[\mathrm{M}+\mathrm{Na}} \\
]^{+}\end{array}$ & $\begin{array}{c}513.2 \\
119\end{array}$ & 26.3 & HCD $(20)$ & $513.2129(100) 496.1858(65) 468.1930(4)$ \\
\hline $\begin{array}{c}\text { PVer_513.2 } \\
\text { 1_26.7 }\end{array}$ & $\begin{array}{c}\mathrm{C}_{27} \mathrm{H}_{30} \mathrm{~N}_{4} \\
\mathrm{O}_{5}\end{array}$ & $\begin{array}{c}{[\mathrm{M}+\mathrm{Na}} \\
]^{+}\end{array}$ & $\begin{array}{c}513.2 \\
119\end{array}$ & 26.7 & HCD $(20)$ & $513.2134(92) 496.1855(100)$ \\
\hline $\begin{array}{c}\text { PVer_513.2 } \\
\text { 1_27.1 } \\
\end{array}$ & $\begin{array}{c}\mathrm{C}_{27} \mathrm{H}_{30} \mathrm{~N}_{4} \\
\mathrm{O}_{5} \\
\end{array}$ & $\begin{array}{c}{[\mathrm{M}+\mathrm{Na}} \\
]^{+}\end{array}$ & $\begin{array}{c}513.2 \\
119 \\
\end{array}$ & 27.1 & $\operatorname{HCD}(20)$ & $513.2128(63) 496.1852(100)$ \\
\hline $\begin{array}{c}\text { PVer_513.2 } \\
1 \_30.1\end{array}$ & $\begin{array}{c}\mathrm{C}_{27} \mathrm{H}_{30} \mathrm{~N}_{4} \\
\mathrm{O}_{5} \\
\end{array}$ & $\begin{array}{c}{[\mathrm{M}+\mathrm{Na}} \\
]^{+}\end{array}$ & \begin{tabular}{|c|}
513.2 \\
119 \\
\end{tabular} & 30.1 & $\operatorname{HCD}(20)$ & $513.2129(40) 496.1857(100) 351.1769(10)$ \\
\hline $\begin{array}{c}\text { PVer_513.2 } \\
1 \_31.4 \\
\end{array}$ & $\begin{array}{c}\mathrm{C}_{27} \mathrm{H}_{30} \mathrm{~N}_{4} \\
\mathrm{O}_{5}\end{array}$ & $\begin{array}{c}{[\mathrm{M}+\mathrm{Na}} \\
]^{+}\end{array}$ & $\begin{array}{c}513.2 \\
119 \\
\end{array}$ & 31.4 & HCD $(20)$ & $513.2134(55) 496.1863(100)$ \\
\hline $\begin{array}{c}\text { PVer_523.2 } \\
\text { 5_25.8 }\end{array}$ & $\begin{array}{c}\mathrm{C}_{28} \mathrm{H}_{36} \mathrm{~N}_{4} \\
\mathrm{O}_{6}\end{array}$ & {$[\mathrm{M}-\mathrm{H}]$} & $\begin{array}{c}523.2 \\
555\end{array}$ & 25.8 & $\operatorname{HCD}(60)$ & $523.2562(5)$ 401.2204(100) 262.1565(16) 135.0455(16) 172.1097(10) 214.1570(4) \\
\hline $\begin{array}{c}\text { PVer_511.2 } \\
\text { 9_18.0 } \\
\end{array}$ & $\mathrm{C}_{28} \mathrm{H}_{38} \mathrm{~N}_{4}$ & $\begin{array}{c}{[\mathrm{M}+\mathrm{H}]} \\
+\end{array}$ & $\begin{array}{c}511.2 \\
909 \\
\end{array}$ & 180 & HCD $(20)$ & \begin{tabular}{|lllllll}
$511.2906(10)$ & $265.1542(100)$ & $219.1488(30)$ & $247.1438(21)$ & $120.0804(16)$ & $394.2120(10)$ & $412.2228(9)$ \\
$349.1902(3) 295.1438(3) 267.1484(2)$ & & & & \\
\end{tabular} \\
\hline $\begin{array}{c}\text { PVer_509.2 } \\
8 \_18.0\end{array}$ & $\mathrm{O}_{5}$ & {$[\mathrm{M}-\mathrm{H}]^{-}$} & \begin{tabular}{|c|}
509.2 \\
769
\end{tabular} & 10.0 & $\operatorname{HCD}(60)$ & \begin{tabular}{|lllllll}
$509.2769(17)$ & $116.0722(100)$ & $276.1033(66)$ & $115.0882(55)$ & $202.1442(32)$ & $146.0616(22)$ & $263.1405(16)$ \\
$164.0722(12)$ & $262.1566(11) 246.1141(8) 174.0565(4)$ & & & \\
\end{tabular} \\
\hline
\end{tabular}




\begin{tabular}{|c|c|c|c|c|c|c|c|c|c|c|}
\hline $\begin{array}{c}\text { PVer_511.2 } \\
9 \_18.7 \\
\end{array}$ & \multirow{2}{*}{$-\begin{array}{c}\mathrm{C}_{28} \mathrm{H}_{38} \mathrm{~N}_{4} \\
\mathrm{O}_{5}\end{array}$} & $\begin{array}{c}{[\mathrm{M}+\mathrm{H}]} \\
+\end{array}$ & $\begin{array}{c}511.2 \\
909\end{array}$ & \multirow{2}{*}{18.7} & $\operatorname{HCD}(20)$ & \multicolumn{5}{|l|}{$166.0858(6) 301.1904(6)$} \\
\hline \begin{tabular}{|c|} 
PVer_509.2 \\
$8 \_18.7$ \\
\end{tabular} & & {$[\mathrm{M}-\mathrm{H}]^{-}$} & $\begin{array}{c}509.2 \\
769\end{array}$ & & HCD (60) & \begin{tabular}{|lrl}
$509.2769(16)$ & $164.0722(100)$ & $219.1506(20)$ \\
$214.1564(7)$ & $343.2139(6) 361.2249(5)$
\end{tabular} & $147.0457(19)$ & $318.2191(10)$ & $465.2877(15)$ & $263.1404(6)$ \\
\hline \begin{tabular}{|c|} 
PVer_525.2 \\
7_13.0 \\
\end{tabular} & $\begin{array}{c}\mathrm{C}_{28} \mathrm{H}_{38} \mathrm{~N}_{4} \\
\mathrm{O}_{6} \\
\end{array}$ & {$[\mathrm{M}-\mathrm{H}]^{-}$} & $\begin{array}{c}525.2 \\
720 \\
\end{array}$ & 13.0 & $\operatorname{HCD}(60)$ & \begin{tabular}{|lrl}
$525.2730(18)$ & $116.0722(100)$ & $292.0982(87)$ \\
$115.0882(18)$ & $248.1087(13)$ & $142.0667(13) 202.12$ \\
\end{tabular} & $\begin{array}{l}172.1096(59) \\
242(12)\end{array}$ & $278.1515(22)$ & $162.0566(24)$ & 263.1405(20) \\
\hline \begin{tabular}{|c|} 
PVer_509.2 \\
$9 \_26.2$ \\
\end{tabular} & $\begin{array}{c}\mathrm{C}_{30} \mathrm{H}_{38} \mathrm{~N}_{4} \\
\mathrm{O}_{2} \\
\end{array}$ & $\begin{array}{c}{[\mathrm{M}+\mathrm{Na}} \\
]^{+}\end{array}$ & $\begin{array}{c}509.2 \\
894 \\
\end{array}$ & 26.2 & HCD (20) & $509.2899(40) 242.1651(100) 111.0915(20) 378.2$ & $2171(12) 351.1$ & $1741(6)$ & & \\
\hline \begin{tabular}{|c|c|} 
PVer_509.2 \\
$9 \_25.2$ \\
\end{tabular} & $\begin{array}{c}\mathrm{C}_{30} \mathrm{H}_{38} \mathrm{~N}_{4} \\
\mathrm{O}_{2} \\
\end{array}$ & $\begin{array}{c}{[\mathrm{M}+\mathrm{Na}} \\
]^{+}\end{array}$ & \begin{tabular}{|c|}
509.2 \\
894 \\
\end{tabular} & 25.2 & HCD (20) & $509.2895(100) 242.1651(83) 111.0915(16) 378.2$ & $.2171(40)$ & & & \\
\hline \begin{tabular}{|c|} 
PVer_509.2 \\
$9 \_23.0$ \\
\end{tabular} & $\begin{array}{c}\mathrm{C}_{30} \mathrm{H}_{38} \mathrm{~N}_{4} \\
\mathrm{O}_{2} \\
\end{array}$ & $\begin{array}{c}{[\mathrm{M}+\mathrm{Na}} \\
]^{+}\end{array}$ & \begin{tabular}{|c|}
509.2 \\
894 \\
\end{tabular} & 23.0 & HCD (20) & $509.2895(73) 242.1347(100) 378.2168(13) 111.0$ & $.0913(13)$ & & & \\
\hline \begin{tabular}{|c|c|} 
PVer_509.2 \\
$9 \_24.4$ \\
\end{tabular} & $\begin{array}{c}\mathrm{C}_{30} \mathrm{H}_{38} \mathrm{~N}_{4} \\
\mathrm{O}_{2} \\
\end{array}$ & $\begin{array}{c}{[\mathrm{M}+\mathrm{Na}} \\
]^{+}\end{array}$ & \begin{tabular}{|c|}
509.2 \\
894 \\
\end{tabular} & 24.4 & HCD (20) & $509.2898(50) 242.1648(100) 378.2159(19) 111.0$ & $.0913(19) 478.0$ & $047(5)$ & & \\
\hline \begin{tabular}{|c|c|} 
PVer_548.2 \\
$9 \_17.4$ \\
\end{tabular} & $\begin{array}{c}\mathrm{C}_{30} \mathrm{H}_{39} \mathrm{~N}_{5} \\
\mathrm{O}_{5} \\
\end{array}$ & {$[\mathrm{M}-\mathrm{H}]^{-}$} & $\begin{array}{c}548.2 \\
892 \\
\end{array}$ & 17.4 & $\operatorname{HCD}(60)$ & \begin{tabular}{|llll}
$548.2892(10)$ & $116.0722(100)$ & $259.1457(65)$ & 1 \\
$302.1515(15)$ & & & \\
\end{tabular} & $186.0565(45)$ & $315.1144(30)$ & $419.2307(20)$ & $271.1252(15)$ \\
\hline \begin{tabular}{|c|c|} 
PVer_548.2 \\
$9 \_18.0$ \\
\end{tabular} & \begin{tabular}{c|}
$\mathrm{C}_{30} \mathrm{H}_{39} \mathrm{~N}_{5}$ \\
$\mathrm{O}_{5}$ \\
\end{tabular} & {$[\mathrm{M}-\mathrm{H}]^{-}$} & \begin{tabular}{|c|}
548.2 \\
892 \\
\end{tabular} & 18.0 & $\operatorname{HCD}(60)$ & \begin{tabular}{|lll}
$548.2892(15)$ & $116.0722(100)$ & $172.1094(100)$ \\
$419.2306(5)$
\end{tabular} & $315.1141(50)$ & $258.1600(22)$ & $271.1242(18)$ & $186.0565(15)$ \\
\hline \begin{tabular}{|c|c|} 
PVer_548.2 \\
$9 \_19.1$ \\
\end{tabular} & $\begin{array}{c}\mathrm{C}_{30} \mathrm{H}_{39} \mathrm{~N}_{5} \\
\mathrm{O}_{5} \\
\end{array}$ & {$[\mathrm{M}-\mathrm{H}]^{-}$} & \begin{tabular}{|c|}
548.2 \\
892 \\
\end{tabular} & 19.1 & $\operatorname{HCD}(60)$ & \begin{tabular}{|lll}
$548.2892(12)$ & $164.0722(100)$ & $202.0990(40)$ \\
$318.2193(8)$ & $301.1675(7) 253.1677(5)$ \\
\end{tabular} & $375.2409(32)$ & $147.0457(18)$ & $219.1505(10)$ & $271.1780(8)$ \\
\hline \begin{tabular}{|c|} 
PVer_564.2 \\
$8 \_12.6$ \\
\end{tabular} & $\begin{array}{c}\mathrm{C}_{30} \mathrm{H}_{39} \mathrm{~N}_{5} \\
\mathrm{O}_{6} \\
\end{array}$ & {$[\mathrm{M}-\mathrm{H}]^{-}$} & $\begin{array}{c}564.2 \\
828 \\
\end{array}$ & 12.6 & $\operatorname{HCD}(60)$ & \begin{tabular}{|lll}
$553.2814(15)$ & $116.0721(100)$ & $202.0513(72)$ \\
$302.1512(12)$ & $278.1515(12)$ & $155.0831(11) 241.13$
\end{tabular} & $\begin{array}{l}285.1937(55) \\
352(8)\end{array}$ & $19.0507(45)$ & $(30)$ & 435.2 \\
\hline $\begin{array}{c}\text { PVer_567.0 } \\
9 \_26.3 \\
\end{array}$ & $\begin{array}{c}\mathrm{C}_{31} \mathrm{H}_{20} \mathrm{O}_{1} \\
1\end{array}$ & {$[\mathrm{M}-\mathrm{H}]^{-}$} & $\begin{array}{c}567.0 \\
941 \\
\end{array}$ & 26.3 & $\operatorname{HCD}(60)$ & $567.0941(100) 523.1042(97) 257.0462(86) 265.0$ & $.0510(55) 309.0$ & $402(30) 256.037$ & $76(20)$ & \\
\hline $\begin{array}{c}\text { PVer_567.0 } \\
9 \_25.1 \\
\end{array}$ & $\begin{array}{c}\mathrm{C}_{31} \mathrm{H}_{20} \mathrm{O}_{1} \\
1\end{array}$ & {$[\mathrm{M}-\mathrm{H}]^{-}$} & $\begin{array}{c}567.0 \\
941 \\
\end{array}$ & 25.1 & $\operatorname{HCD}(60)$ & $567.0941(60) 523.1042(100) 439.0817(17)$ & & & & \\
\hline \begin{tabular}{|c|} 
PVer_523.3 \\
$0 \_27.7$ \\
\end{tabular} & $\begin{array}{c}\mathrm{C}_{31} \mathrm{H}_{40} \mathrm{~N}_{4} \\
\mathrm{O}_{2} \\
\end{array}$ & $\begin{array}{c}{[\mathrm{M}+\mathrm{Na}} \\
]^{+}\end{array}$ & $\begin{array}{c}523.3 \\
047 \\
\end{array}$ & 27.7 & HCD (20) & $523.3038(12) 266.1168(100)$ & & & & \\
\hline \begin{tabular}{|c|c|} 
PVer_523.3 \\
$0 \_27.4$ \\
\end{tabular} & $\begin{array}{c}\mathrm{C}_{31} \mathrm{H}_{40} \mathrm{~N}_{4} \\
\mathrm{O}_{2} \\
\end{array}$ & $\begin{array}{c}{[\mathrm{M}+\mathrm{Na}} \\
]^{+}\end{array}$ & \begin{tabular}{|c|}
523.3 \\
047 \\
\end{tabular} & 27.4 & HCD (20) & $523.3058(62) 266.1170(100)$ & & & & \\
\hline \begin{tabular}{|c|} 
PVer_507.2 \\
$8 \_38.5$ \\
\end{tabular} & $\begin{array}{c}\mathrm{C}_{32} \mathrm{H}_{36} \mathrm{~N}_{4} \\
\mathrm{O}_{2} \\
\end{array}$ & {$[\mathrm{M}-\mathrm{H}]^{-}$} & \begin{tabular}{|c|}
507.2 \\
760 \\
\end{tabular} & 38.5 & $\operatorname{HCD}(60)$ & $507.2762(100) 236.0728(70)$ & & & & \\
\hline \begin{tabular}{|c|} 
PVer_537.2 \\
$9 \_39.5$ \\
\end{tabular} & $\mathrm{C}_{32} \mathrm{H}_{42} \mathrm{O}_{7}$ & {$[\mathrm{M}-\mathrm{H}]^{-}$} & $\begin{array}{c}537.2 \\
867 \\
\end{array}$ & 39.5 & $\operatorname{HCD}(60)$ & \begin{tabular}{|llll}
$537.2867(3)$ & $71.0507(100)$ & $95.0507(80)$ & 14 \\
$399.2701(12)$ & & & \\
\end{tabular} & $\begin{array}{ll}47.0821(55) \quad 1 \\
\end{array}$ & $159.1185(30) \quad 4$ & $417.2810(25)$ & $321.2230(15)$ \\
\hline \begin{tabular}{|c|} 
PVer_553.2 \\
8_38.7 \\
\end{tabular} & $\mathrm{C}_{32} \mathrm{H}_{42} \mathrm{O}_{8}$ & {$[\mathrm{M}-\mathrm{H}]^{-}$} & \begin{tabular}{|c|}
553.2 \\
814 \\
\end{tabular} & 38.7 & $\operatorname{HCD}(60)$ & $553.2814(25) 175.1133(100) 121.0663(35) 97.03$ & $300(23) 253.16$ & $502(6)$ & & \\
\hline \begin{tabular}{|c|} 
PVer_553.2 \\
$8 \_38.3$ \\
\end{tabular} & $\mathrm{C}_{32} \mathrm{H}_{42} \mathrm{O}_{8}$ & {$[\mathrm{M}-\mathrm{H}]^{-}$} & \begin{tabular}{|c|}
553.2 \\
814 \\
\end{tabular} & 38.3 & $\mathrm{HCD}(60)$ & $\begin{array}{|lll|}553.2814(5) & 175.1133(100) & 121.0663(72) \\
119.0507(19) & & \\
\end{array}$ & $97.0300(66)$ & $201.0926(15) \quad 3$ & $393.1443(10)$ & $135.0820(19)$ \\
\hline \begin{tabular}{|c|} 
PVer_623.3 \\
$2 \_36.3$
\end{tabular} & \multirow{2}{*}{$\mid \begin{array}{c}\mathrm{C}_{37} \mathrm{H}_{42} \mathrm{~N}_{4} \\
\mathrm{O}_{5}\end{array}$} & $\begin{array}{c}{[\mathrm{M}+\mathrm{H}]} \\
+\end{array}$ & $\begin{array}{c}623.3 \\
215\end{array}$ & \multirow{2}{*}{36.3} & HCD (20) & $623.3226(2) 373.2386(100) 242.1653(25) 251.09$ & $916(13) 111.09$ & $16(3)$ & & \\
\hline \begin{tabular}{|c|} 
PVer_621.3 \\
$0 \_36.3$ \\
\end{tabular} & & {$[\mathrm{M}-\mathrm{H}]^{-}$} & $\begin{array}{c}621.3 \\
073 \\
\end{array}$ & & HCD (40) & $621.3091(5) 371.2249(100) 249.0773(62)$ & & & & \\
\hline $\begin{array}{c}\text { PVer_713.2 } \\
8 \_33.4 \\
\end{array}$ & $\begin{array}{c}\mathrm{C}_{38} \mathrm{H}_{42} \mathrm{~N}_{4} \\
\mathrm{O}_{10}\end{array}$ & {$[\mathrm{M}-\mathrm{H}]^{-}$} & \begin{tabular}{|c|}
713.2 \\
847
\end{tabular} & 33.4 & HCD (60) & $\begin{array}{|lll|}713.2847(2) & 190.0276(100) & 191.0355(65) \\
400.2126(2) & & \\
\end{array}$ & $309.0411(22)$ & $161.0249(17)$ & $311.0567(12)$ & $325.0723(9)$ \\
\hline
\end{tabular}

